\title{
An Overview of Electrokinetic Soil Flushing and Its Effect on Bioremediation of Hydrocarbon Contaminated Soil
}

\author{
Bimastyaji Surya Ramadan ${ }^{\mathrm{a}}$, Gina Lova Sari ${ }^{\mathrm{b}}$, Raden Tina Rosmalina ${ }^{\mathrm{c}}$, Agus Jatnika Effendi ${ }^{\mathrm{d}}$, \\ $\operatorname{Hadrah}^{\mathrm{e}}$
}

${ }^{a}$ Faculty of Environmental Engineering, Institut Teknologi Yogyakarta, Yogyakarta-55171, Indonesia (bimastyajisurya@gmail.com)

${ }^{\mathrm{b}}$ Faculty of Engineering, Universitas Singaperbangsa, Karawang-41361, Indonesia (ginalovasari@gmail.com)

${ }^{\mathrm{c}}$ Research Unit for Clean Technology, LIPI-40135, Indonesia (tinarosmalina@yahoo.com)

${ }^{a}$ Department of Environmental Engineering, Faculty of Civil and Environmental Engineering, Institut Teknologi Bandung, Bandung-40132, Indonesia (jatnika@indo.net.id)

${ }^{\mathrm{e}}$ Department of Environmental Engineering, Faculty of Engineering, Universitas Batanghari, Jambi-36122, Indonesia (hadrah.hasan@gmail.com)

\section{Corresponding Author}

Bimastyaji Surya Ramadan; Faculty of Environmental Engineering, Institut Teknologi Yogyakarta, Yogyakarta-55171, Indonesia (bimastyajisurya@gmail.com)

\section{HIGHLIGHTS}

- Fundamental interaction between electrokinetic soil flushing and bioremediation in contaminated soil are reviewed

- Recent progress and development of electrokinetic soil flushing and bioremediation are highlighted

- Sustainability assessment and future perspectives of electrokinetic soil flushing and bioremediation are summarized

\begin{abstract}
Combination of electrokinetic soil flushing and bioremediation (EKSF-Bio) technology has attracted many researchers attention in the last few decades. Electrokinetic is used to increase biodegradation rate of microorganisms in soil pores. Therefore, it is necessary to use solubilizing agents such as surfactants that can improve biodegradation process. This paper describes the basic understanding and recent development associated with electrokinetic soil flushing, bioremediation, and its combination as innovative hybrid solution for treating hydrocarbon contaminated soil. Surfactant has been widely used in many studies and practical applications in remediation of
\end{abstract}


hydrocarbon contaminant, but specific review about those combination technology cannot be found. Surfactants and other flushing/solubilizing agents have significant effects to increase hydrocarbon remediation efficiency. Thus, this paper is expected to provide clear information about fundamental interaction between electrokinetic, flushing agents and bioremediation, principal factors, and an inspiration for ongoing and future research benefit.

Keywords: electrokinetic soil flushing, bioremediation, surfactant, flushing agents, EKSF-Bio

\section{Introduction}

Electrokinetic remediation, often called electroreclamation, electrochemical soil remediation, and electrodecontamination are technologies that use weak electric field to remove and degrade organic, inorganic, and heavy metal compounds from surface of soil particles (Acar et al., 1995; Kim et al., 2010). Electrokinetic remediation has been studied for over last 2 decades (Cameselle et al., 2013). This technology has grown considerably, followed by the emergence of innovative and efficient new patents and studies (Annamalai et al., 2017; Marks et al., 1995). Some literature reviews mention the success of this technology and its integration with other technologies in both laboratory and pilot scale (Lima et al., 2017; Pham and Sillanpää, 2015). Nevertheless, the application of electrokinetic technology in the field is still rare to be found because it is more costly compared to other technologies (Kim et al., 2011) and has some limitations that still need to be concerned such as high temperature and evaporation rate, heterogeneous soil conditions, corrosion in electrode, $\mathrm{pH}$ control and electrical source availability in isolated areas (Environmental Protection Agency, 2007). The United States Environmental Protection Agency (2017) reports that electrokinetic technology has not been used since 1992 to recover contaminated groundwater.

Bioremediation is the most commonly technique used for remediation of contaminated soil due to its cheapness and convenience. In addition, microorganisms are very abundant to be found in natural soil, either in the form of a consortium attached to soil particles or suspended in soil pore ecosystem. This finding shows a great potential for conducting bioremediation of contaminated soil. However, bioremediation have several limitations, including environmental condition, electron acceptors and nutrients, nature of contaminants, microbial and metabolism growth (Hassan et al., 2016a; Lahel et al., 2016). Electrokinetic can solve those limitation and enhance process efficiency especially on low permeability soil which contain high percentage of clay or silt. Electrokinetic phenomena can transfer several contaminant, nutrient, and also microorganism through electroosmosis, electrophoresis, and electromigration process (Lear et al., 2007; Mena et al., 2016a; Wang et al., 2016). This integration is often called electro-bioremediation, electrokinetic 
bioremediation (EK-Bio) and bioremediation assisted by electrokinetic (Barba et al., 2017; Choi et al., 2009; Wang et al., 2016). Surfactants are able to act as solubilization agents that enhance biodegradation rate of hydrocarbon contaminants. Surfactants can reduce surface tension and increase solubility of hydrocarbon contaminants through a process called micellar solubilization (Lima et al., 2011). In electrokinetic system, surfactants may be added in the electrolyte chambers and flushed to soil pores through electrokinetic mechanism (some researchers often call it electrokinetic soil flushing/EKSF) and mixed it directly into the reactor (Reddy and Cameselle, 2010; Vieira dos Santos et al., 2016). This combined technology has been successfully remove hydrocarbon contaminant from soil (Mena et al., 2016c; Ramírez et al., 2015). Table 1 describes different performance of EKSF-Bio as standalone technology in treating hydrocarbon contaminated soil.

\section{Table 1}

Different performance of electrokinetic soil flushing and bioremediation as standalone technology

\begin{tabular}{|c|c|c|}
\hline Differences & Electrokinetic soil flushing & Bioremediation \\
\hline Hydrocarbon removal & $\begin{array}{l}\text { Removal of hydrocarbon } \\
\text { contaminants from soil using } \\
\text { electrochemical mechanism. } \\
\text { Hydrocarbons are released from } \\
\text { soil particles and flushed through } \\
\text { soil pores into the electrode } \\
\text { chambers for ex-situ treating (pump } \\
\text { and treat) }\end{array}$ & $\begin{array}{l}\text { Bioremediation can be performed } \\
\text { using nutrient stimulation or } \\
\text { engineered environmental conditions } \\
\text { that suitable for microorganisms, } \\
\text { bioaugmentation of hydrocarbons } \\
\text { degrader and bioattenuation of } \\
\text { indigenous microorganism }\end{array}$ \\
\hline $\begin{array}{l}\text { Contaminant } \\
\text { transformation }\end{array}$ & $\begin{array}{l}\text { Transformation of pollutants may } \\
\text { occur on the surface of soil particles } \\
\text { or more specifically on the diffuse } \\
\text { double layer. In addition, } \\
\text { contaminant transformation may } \\
\text { occur in each of electrode }\end{array}$ & $\begin{array}{l}\text { Biotransformation can occur if } \\
\text { contaminants accessible and } \\
\text { available for microorganism, mixing } \\
\text { can accelerate the transformation } \\
\text { process }\end{array}$ \\
\hline $\begin{array}{l}\text { Mass transfer } \\
\text { phenomena }\end{array}$ & $\begin{array}{l}\text { The existence of voltage gradient } \\
\text { causes the emergence of some } \\
\text { electrokinetic phenomena that can } \\
\text { bring and drag water, ions, } \\
\text { compounds, colloids or } \\
\text { microorganisms through soil pores }\end{array}$ & $\begin{array}{l}\text { Effective transfer of } \\
\text { microorganisms, substrates, nutrients } \\
\text { and contaminants can be achieved } \\
\text { when external energy / pressure / } \\
\text { assistance such as mixing or } \\
\text { injection has been conducted }\end{array}$ \\
\hline $\begin{array}{l}\text { Main process } \\
\text { parameter }\end{array}$ & Electrokinetic movement & $\begin{array}{l}\text { Ability of microorganisms in } \\
\text { degrading contaminants }\end{array}$ \\
\hline
\end{tabular}


The basic principle of EKSF-Bio as combined technology is how to make hydrophobic contaminants treated in soil without any secondary or tertiary treatment/electrolyte extraction (Gill et al., 2015a; Lima et al., 2017). In case of natural attenuation, this integrated technology is promising because it only need a short period of processing time, between 5-50 days (Ammami et al., 2014; Asgari et al., 2013). Meanwhile, bioremediation needs 14-90 days to exactly degrade and remove contaminant from soil (Gill et al., 2014; Wick et al., 2007). This technique is suitable to be applied both in-situ and ex-situ of hydrocarbon contaminated soil. The electrolyte solution is not only consisted of surfactant and deionized water, but also some enhancing agents such as salts, oxidant, and chelants to cover surfactant limitation (Hahladakis et al., 2014; Mena et al., 2016c; Ramírez et al., 2015).

Electrokinetic and bioremediation (EK-Bio) have been reviewed by many researchers. Wick et al. (2007) has resumed the fundamental interactions between microorganism, soil, and compound in soil pore matrices; Gill et al. (2014) and Hassan et al. (2016) has made a systematic review about electrokinetic phenomena and factors influencing EK-Bio process; Moghadam et al. (2016) have reviewed a combinations of electrokinetic application; Zhong et al. (2017) discussed about surfactant enhancing the transport of bacteria in porous media; and Ren et al. (2018) have studied about sorption, transportation and biodegradation of persistent organic pollutant in soil. However, there is no specific review and discussion about electrokinetic soil flushing and its effect on bioremediation (EKSF-Bio). The purposes of this paper are to analyze the possible combined mechanisms of EKSF-Bio, describe the latest developments and factors affecting EKSF-Bio in treating hydrocarbon contaminated soil, as well as explaining the future challenges and perspectives related to the field application of electrokinetic soil flushing and bioremediation to treat hydrocarbon contaminated soil.

\section{Fundamental interaction in electrokinetic soil flushing and bioremediation (EKSF-Bio)}

Electrokinetic soil flushing - bioremediation is a combination remediation technology that utilizes the interaction of weak electric field (low current/voltage), solubilizing agent and biological processes in remediating hydrocarbon contaminated soil. In principle, biodegradation processes on low permeability soils are enhanced by electrokinetic and flushing agent. Solubilizing agents, contaminants, macro - micro nutrients, oxygen, and various other compounds are transported through soil pores by using electrochemical phenomena. There are three main phenomena that occur when a weak electric field is applied to the soil: electrokinetic, chemical (release of hydrocarbon compounds and solubilization of contaminants in soil matrices), and biological 
phenomena. Fig. 1 shows an illustration of electrokinetic, surfactant, and biological interaction under weak electric field.

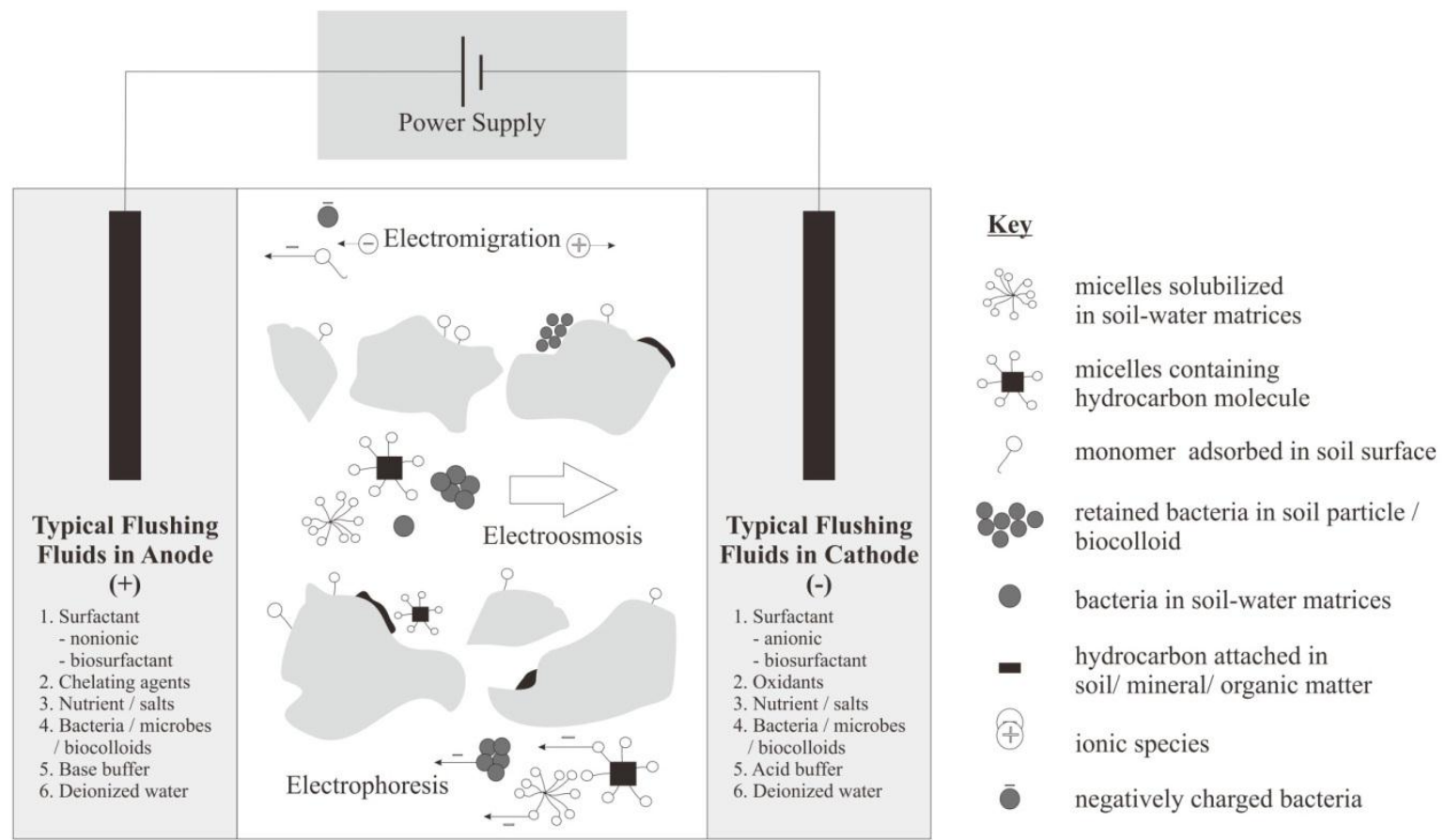

Fig. 1. Electrokinetic, flushing fluids, surfactant and biological interaction under low electric field.

\subsection{Electrokinetic phenomena}

The remediation process begins with providing a weak electric field to the electrode resulting in various reactions, namely: electrolysis, electromigration, electroosmosis, and electrophoresis. Electrolysis is a changing reaction of water molecules/compounds and forms excess of hydrogen ions in anode chamber and hydroxide ions in cathode chamber (Vieira dos Santos et al., 2014).

Anode (Oxidation) $\quad: 2 \mathrm{H}_{2} \mathrm{O} \rightarrow \mathrm{O}_{2}(\mathrm{~g})+4 \mathrm{H}^{+}+4 \mathrm{e}^{-}$

Cathode (Reduction) : $4 \mathrm{H}_{2} \mathrm{O}+4 \mathrm{e}^{-} \rightarrow 2 \mathrm{H}_{2}(\mathrm{~g})+4 \mathrm{OH}^{-}$

As a result of electrode reactions, acid condition will be form in anode (1) and bases in cathode (2). Basically, $\mathrm{pH}$ at the anode will drop dramatically and reach stability at $\mathrm{pH} 2.0-3.0$ while at the cathode $\mathrm{pH}$ will increase to 12.0. This condition has detrimental effect for microorganisms and also electrokinetic forces. By applying an electric field to electrode, ions in soil pores ecosystem move toward to the opposite charge (electromigration). Furthermore, the ions as well as the charged colloids including biocolloid (electrophoresis) in anode, cathode, and soil will migrate towards electrode with opposite charges. Since most clay minerals have a negative charge, negative ions will flow and bring water molecules from anode chamber to the cathode chamber (electroosmosis). These reactions play an important role in removing contaminants from soil particles and bringing them close to electrode chambers (Acar et al., 1995; Gill et al., 2014; Hassan et al., 2016a). The 
positive ions and negative charge of soil particle around soil pore are then affixed to clay surface causing the emergence of diffuse double layer (DDL) in surface of soil particles. This mechanism is very important in EKSF-Bio as it relates to the transportation and removal of contaminants from soil particles (Asgari et al., 2013; Cameselle, 2015; Hassan et al., 2016a)

In EKSF-Bio, there are two kinds of hydrocarbon degradation processes that occur, namely electrokinetic transformation (electro-oxidation) and biodegradation/biotransformation. After passing soil pore through electro-transportation process, the contaminants that still attached to soil particle are transformed by oxidation - reduction mechanism in which the clay surface acts as a micro electrode (Hassan et al., 2016b; Yuan et al., 2013). Diffuse Double Layer (DDL) is formed around charged soil particle surface. Diffuse/electrical double layer (DDL) is a layer/zone that arises due to an electric current where the surface of a negatively charged soil particle will be filled with positively charged cations. DDL contains ions (both positive and negative) which are adsorbed to the surface of organic/soil compounds due to chemical interactions and the layer that contain free moving ions in the pore fluid. DDL thickness is affected by soil surface charge density, ion concentration in fluid, cation valence, and dielectric constant of fluid. Fig. 2. illustrates diffuse double layer in soil particle matrices which occur under weak electric field.

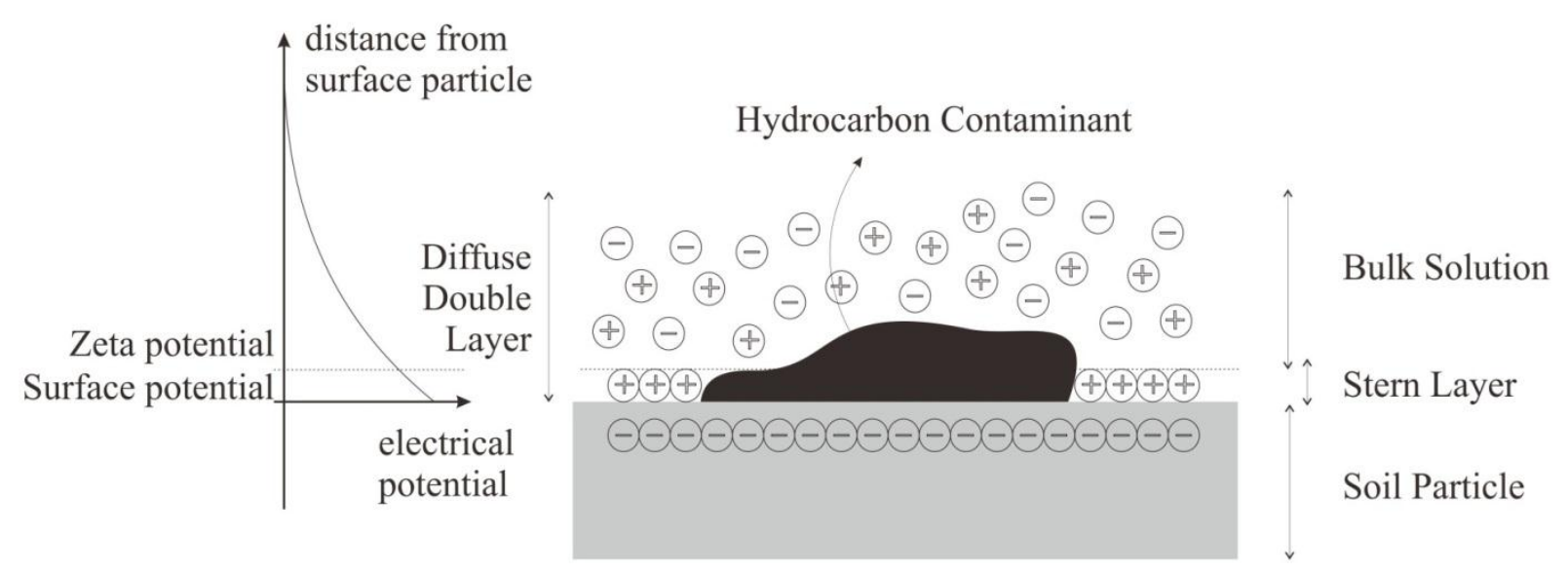

Fig. 2. Diffuse double layer in soil particle matrices which occur under low electric field (adapt from Cameselle, 2015).

Zeta potential will decrease further as increase of distance from surface particle. Meanwhile, electric potential will increase close to soil particle. In general, clay particles surface is negatively charged, so that the positively charged ions will be attracted to its surface. Excessive negative or positive ions will migrate toward the opposite electrode resulting in electroosmosis. Faradic reaction will also occur on the surface of clay particles where DDL will become micro-"anode" and 
"cathode" so oxidation-reduction process can occur. The higher the concentration of electrolyte, the greater the possibility of oxidation process happen (Acar et al., 1995; Cameselle, 2015; Reddy and Chinthamreddy, 2004; Yeung and Gu, 2011).

\subsection{Soil flushing and sorption}

Flushing solutions that are often used to remove hydrocarbon contaminants are surfactants because it can reduce surface tension and increase contaminant solubilization. However, mixed enhancing agents is indispensable for addressing more complex contaminants (Hahladakis et al., 2014; Ramirez et al., 2015). Surfactants are commonly used to increase the desorption rate of hydrocarbon compounds from soil minerals/organic matter and increase the solubility by dividing and capturing them into colloidal molecules/aggregates that can move freely in liquid phase (Fan et al., 2014; Saichek and Reddy, 2005). Surfactants can be adsorbed on the soil matrix (depending on their ionic structure), thereby reducing the efficiency of the removal process. The key of success of electrokinetic soil flushing using surfactants is how to maintain the effectiveness of contaminant solubilization and electroosmotic rate (Ammami et al., 2015; Tao and Chengxun, 2016; Vieira dos Santos et al., 2016). The mechanism of hydrocarbon contaminants removal enhanced by surfactant that is divided into 3 main phases, the first is the breaking of hydrocarbon bonds from particles/soil mineral then the transportation of hydrocarbon using micelles under weak electric field and the last is the complex interaction between contaminant, soil minerals, surfactants, and solution compositions/enhancement agents contained in EK system. Surfactants movements in the pores may be inhibited by surfactant adsorption process and soil pore blockage potential (Li et al., 2012a; Lim et al., 2016; Park et al., 2007).

The use of surfactants in electrokinetic process, has several influences such as increasing electrical double layer interaction and potential zeta changes which then affect electroosmotic flux. Zeta potential is the key parameter to determine electrokinetic reactions in soil water pore matrices. The presence of cationic surfactant makes zeta potential more positive on acid condition and vice versa, the presence of anionic surfactant lowers zeta potential value. Non-ionic surfactants were also able to decrease potential zeta values although not as much as anionic surfactants. A more negative zeta potential indicates the addition of cations to a particular medium. Zeta potential value varies from anode to cathode, but tends to be negative toward positive. Zeta potential depends on $\mathrm{pH}$ and ion concentration in the solution. Specific conductance indicates the presence of dissolved ions in the soil pore ecosystem (Paramkusam et al., 2015). This suggests the potential of colloidal precipitation which is greater in cationic surfactant than others. It shows that cationic surfactants are not suitable 
for electrokinetic soil flushing enhanced bioremediation (Ammami et al., 2014; Boulakradeche et al., 2015; Kaya and Yukselen, 2005).

Due to hydrophilic and hydrophobic group structure, surfactant may draw part of hydrophobic contaminant compound and protect it from water molecules. After bounded in micelles, the compound is mobilized by an electric field. The micelle movement depends on the type of surfactant used, where non-ionic surfactant will move to cathode while anionic surfactant will move to anode (Ammami et al., 2014). The amount of non-ionic surfactants that can be adsorbed by soil particles is considerable where the amount of surfactant adsorbed will increase as the surfactant concentration increases to equilibrium (Cheng et al., 2017). There is a good affinity between nonionic surfactants and the soil surface when the concentration of equilibrium is below CMC. Nonionic surfactants are adsorbed in the form of monomers and form a parallel layer between the surface of the soil with both the hydrophilic and hydrophobic part of surfactant. The surfactant monomer can be adsorbed by soil as the result of ion-dipole-type interactions. When the surfactant concentration is above the $\mathrm{CMC}$, adsorption by soil decreases sharply due to the formation of micelles/bilayers through hydrophobic association/interactions with hydrogen bonding (Alcántara et al., 2012; Lim et al., 2016). Since the anionic surfactant has the same negative charge as soil particles, this type of surfactant actually obtain a very large electrostatic repulsion force. As a result, only a few monomers are adsorbed on the soil particles surface (Huang et al., 2012).

\subsection{Biodegradation}

Basically, EKSF-Bio can be applied directly to contaminated soil by using indigenous microorganisms (Kim et al., 2010; Li et al., 2010; Yuan et al., 2013). Nutrients and electron acceptors are transferred through soil pores by electrokinetic processes so that increasing bioavailability of contaminants. If the environmental conditions do not support microorganisms growth, electrokinetic can transmit a number of nutrients, electron acceptors, complexing agents, and also surfactant to microorganisms so biodegradation limitation in soil can be reduced (Annamalai et al., 2017; Da Rocha et al., 2009; Guo et al., 2014; Li et al., 2012b; Luo et al., 2006; Mena et al., 2016c). Several researches also suggest that microorganisms can be flushed into soil to improve removal efficiency because indigenous microorganisms can not treat hydrocarbon contaminants effectively (Asgari et al., 2013; Kim et al., 2005; Mao et al., 2012).

Biotransformation is strongly influenced by direct electric current (DC). Microorganisms that consume hydrocarbon compounds can be catabolically active in weak electric fields. Cell physiology is not affected by low voltage (below $0.3-2.0 \mathrm{~V} / \mathrm{cm}$ ) but can be destroyed at high 
voltage $(>1 \mathrm{kV} / \mathrm{cm})$. Biotransformation occurs due to the transfer of contaminants and nutrients into the cell body through electro-movement process. Hydrocarbon degradation rate varies on the complexity of the compound. This biodegradation occurs on clay surface and corresponds to electrokinetic transformation process. Several researchers have suggested that the application of electric fields can increase the production of ATP in order to improve the performance of cells in consuming hydrocarbon compounds (Reddy and Chinthamreddy, 2004; Yeung and Gu, 2011). Critical factors affecting the biotransformation process are drastic changes in $\mathrm{pH}$ and the inability of the system to deliver substrates and nutrients to microorganisms. Drastic $\mathrm{pH}$ changes that occur in surrounding area of electrode can make soil $\mathrm{pH}$ drastically lower and cause stress in microorganisms consortium that are intolerant with $\mathrm{pH}$ changes. Electroosmosis direction can also be reversed naturally if the whole soil becomes acidic (electroendosmosis). Acid condition can break and alter the minerals bonds such as chlorite, calcite and Fe/Mn oxide so that PAHs can be detached from soil particles (Giannis et al., 2012). In other hand, this condition also causing substrate and nutrients not distributed properly so that imperfect biodegradation occur. Fig. 3 illustrates the possible mechanism of surfactant as flushing fluids and microorganism under weak electric field.

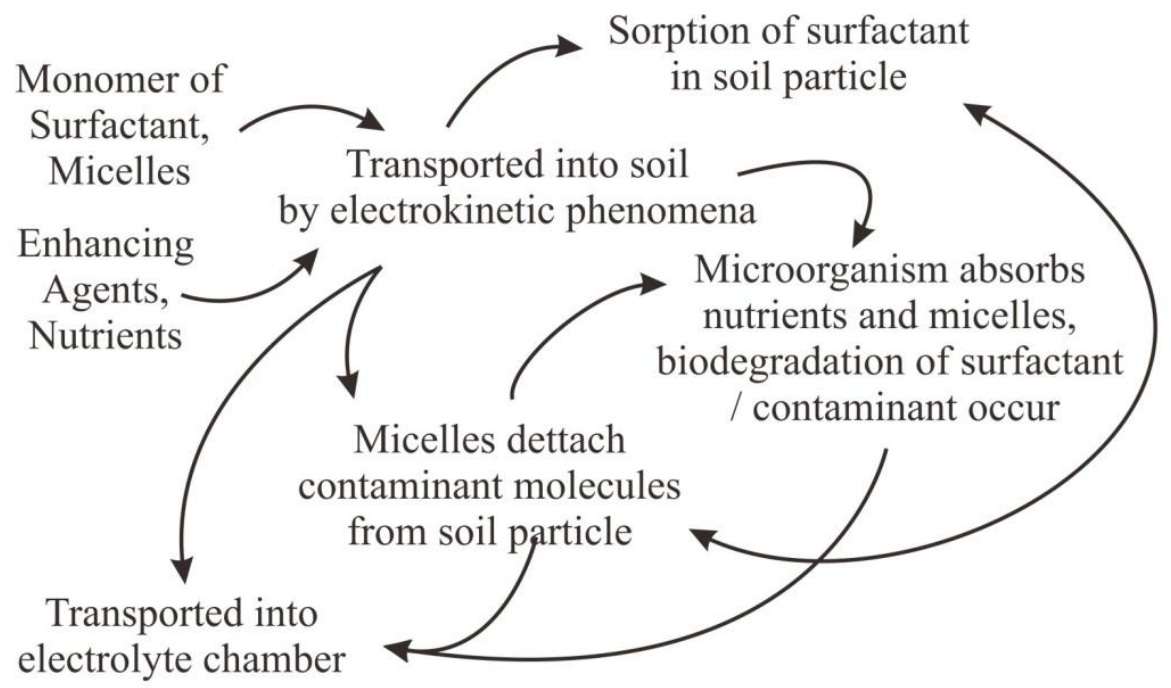

Fig. 3. Schematic mechanism of surfactant as flushing fluids and microorganism under low electric field.

Electric current can increase dehydrogenase enzyme activity. This activity is a key parameter to measure biological process in the EKSF-Bio system and demonstrates the oxidation of organic compounds from respiration and metabolic processes (Kim et al., 2010). Microbial cell growth and dehydrogenase activity can be stimulated using oxygen and electrolyte flushing, $\mathrm{pH}$, weak electric 
current/voltage, nutrients, and the duration of treatment. The oxygen produced at the anode causes high dehydrogenase activity in the surrounding anode chamber. The lower the $\mathrm{pH}$ and the longer the processing time will slow the dehydrogenase activity, so finding the most optimal conditions in terms of duration, $\mathrm{pH}$ or nutrient will be useful for maintaining the sustainability of EKSF-Bio system (Fan et al., 2015; Harbottle et al., 2009; Li et al., 2010; She et al., 2006).

\section{Principal factors of electrokinetic soil flushing and bioremediation (EKSF-Bio)}

Several factors affecting EKSF-Bio performance in treating hydrocarbon contaminated soil are: community of microorganisms degrading hydrocarbon compounds; soil characteristics (moisture content, $\mathrm{pH}$, micro and macro-nutrients availability, and also temperature); configuration and electrokinetic system; and the type of hydrocarbon contaminants. While the surface charge, electrolyte properties and viscosity strongly related to electrokinetic soil flushing as single technology (Fan et al., 2015; Gill et al., 2014; Hassan et al., 2016a). The parameters that would be described below are major factors in EKSF-Bio and has recently undergone a fairly rapid development.

\subsection{Microorganism}

Microorganisms can move through soil micro pores from cathode to anode chamber by electromigration and electrophoresis due to the tendency of negatively charged microorganisms at neutral or alkaline $\mathrm{pH}$. However, some microorganisms can be retained adjacent to anode because electroosmotic flow is stronger than electromigration (Maillacheruvu and Chnichoud, 2011; Olszanowski and Piechowiak, 2006). On a micro scale, microorganisms tend to form a consortium (biocolloid) and attached in soil particle. Biocolloid can be transported to anode via electrophoretic mechanism. This mechanism also makes micelles and various colloids transported across soil pore. Microorganisms mobility also strongly depends on surface charge of the cell wall and its tendency to adhere to the soil surface. Microorganisms transport velocity varies from 0.05 to $0.15 \mathrm{~cm}^{2} \mathrm{~V}^{-1} \mathrm{~h}^{-1}$ whereas the hydrocarbon contaminants are in the range of $0.001-0.26 \mathrm{~cm}^{2} \mathrm{~V}^{-1} \mathrm{~h}^{-1}$ (Da Rocha et al., 2009; Maillacheruvu and Chnichoud, 2011; Wick et al., 2004).

Pseudomonas putida is placed in the anode chamber, then the electrokinetic reactor is operated for 5 days with a total voltage gradient of 50 Volts to remove zinc from kaolin soil. Interestingly, bacteria are quite abundant in soil and zinc can be removed for more than $89 \%$ at the end of the research. This shows the presence of bacterial migration to the soil and zinc removal due to bacteria existence (Azhar et al., 2016). Electrokinetics are also known to enhance bioremediation of nitrate and 
ammonium in soil. Choi et al. (2008) reported that denitrification process can be improved due to electroosmosis process that produce organic substances, $\mathrm{H}^{+}$, and $\mathrm{O}_{2}$ from electrolysis reaction in electrode to bacteria on soil. Bacteria undergo neutral or positively charged in its cell surfaces when environment become acid $(\mathrm{pH}=2.0)$. Electroosmosis and physiological activity as well as bacterial metabolism can reduce nitrate in environment due to bioconversion process of nitrate into ammonium ions and ammonium ions into gaseous ammonia in area around cathode chamber (Choi et al., 2009). The success of bioremediation process of diesel contaminated soil is known to use single culture, Bacillus sp. (TMY-2 strain), mixed cultures from contaminated soil and mixed cultures of activated sludge for wastewater treatment (Khodadadi et al., 2011; Mena et al., 2016a). Although some types of microorganism are known to degrade hydrocarbons under electric fields, microbial community (mixed culture) is known to have a stronger potential in degrading more complex organic compounds (Fan et al., 2015; Mena et al., 2014).

\subsection{Environmental condition}

Weak electric field which applied in soil has an positive and negative impact on microorganisms activity. The changes in $\mathrm{pH}$ due to electrolysis lead to a decrease in the diversity and number of microorganisms viability. Although weak electric field can cause changes in metabolic activity and bacterial membrane composition, many researchers suggest that substrate utilization and metabolism of microorganisms increase as a result of direct (electron transfer from electrode to bacteria) and indirect stimulation (transfer of electrons) (Kim et al., 2010; Li et al., 2010; Mena et al., 2014). Previous research has revealed that electrokinetic can increase the number of Bacillus and Arthrobacter (Khodadadi et al., 2011; Lear et al., 2004), and increase the metabolism of some soil bacteria and fungi (Lear et al., 2007). In a research conducted by Li et al. (2010) the rate of alkane biodegradation increases 1.6 times greater than in the absence of an electric field of 1.0 $\mathrm{V} / \mathrm{cm}$. The closer the distance of a contaminant from electrode, the greater the electrical intensity that is owned, so the decrease of contaminants concentration is also greater.

Voltage and electric current are also closely related to the increase in temperature (soil heating) where the higher the voltage, the higher the temperature will be produced in the EKSF-Bio system (Mena et al., 2016b). High temperatures can increase the activity of microorganisms in the biodegradation process of hydrocarbon compounds. The increase in temperature occurs due to the water electrolysis reaction (exothermic reaction) occurring in the anode so heat generated by the process can be transferred through electroosmosis mechanism (Barba et al., 2017). The largest temperature rise in the reactor is located in the area around anode. Increased temperatures can also occur due to ohmic resistance by soil that acts as electrical resistance. Temperature rises can lead to 
the decreased of moisture content and increased the electrical resistance (Yuan et al., 2016; Li et al., 2010b). The decrease in water content is indicated by the crack at the soil surface and decreased of electroosmosis rate. Water movement and vertical contaminants are also considered using a threedimensional distribution. For instance, oxyfluorfen is easily transported toward the anode or cathode due to electrophoresis/electroosmosis. However, oxyfluorfen transport is gravitatively/vertically more difficult when compared to dichlorophenoxyacetic acid/2,4-D (Risco et al., 2016). Temperature rises occurring on a laboratory scale (Mena et al., 2016c) is not high enough (even often ignored) when compared with pilot-scale studies (Mena et al., 2016b) where the temperature can rise from $20^{\circ} \mathrm{C}$ to maximum of $35^{\circ} \mathrm{C}$ in $1 \mathrm{~V} / \mathrm{cm}$ of electric field. Maintaining evaporation is very important for electrokinetics and bioremediation (Mena et al., 2015). Evaporation has $60 \%$ contribution in herbicide removal with water evaporation rate and pesticides respectively of $0.25 \mathrm{~mL} \mathrm{~cm}^{-2} \mathrm{~d}^{-1}$ and $0.02 \mathrm{mg} \mathrm{mL}^{-1} \mathrm{~d}^{-1}$ at 20-25 ${ }^{\circ} \mathrm{C}$ (Vieira dos Santos et al., 2014).

Transfer of electron acceptors is one of critical points to improve biodegradation process. Electrokinetics are known to supply some inorganic nutrients such as nitrates, sulfates, phosphates, ammonium, and oxygen. Nitrates, phosphates, and sulfates are useful in biodegradation processes as macro nutrients and also as electron acceptor providers for microorganisms metabolism. Some previous research have been successful in transferring and distributing these nutrients in the form of ions (Choi et al., 2009; Gill et al., 2015b; Xu et al., 2010). However, biotransformation using oxygen (aerobic) is preferred than using bonded oxygen compounds such as nitrate or sulfate. The water electrolysis reaction that occurs in anode causes the emergence of aerobic conditions that are beneficial to microorganisms. In fact, only a small amount of oxygen can be transported to the soil (less than $1 \%$ of oxygen in the anode). The oxygen percentage in anode chamber can be properly transported when the electrolyte concentration is lowered, the anode pressure is increased, the voltage output is magnified and applied to the soil having greater permeability. Certainly, this will have a negative impact on biodegradation process and there is a need for further research to find out the best mechanism for transferring oxygen to the soil with low permeability (Ramírez et al., 2015, 2014). Decreased efficiency experienced due to the lack of nutrient transferred to soil is also experienced by previous studies using 2-D EKSF-Bio. This shows that nutrient such as nitrates and phosphates limit the viability of microorganisms (Vieira dos Santos et al., 2016).

Soil properties has an influence in electrokinetic process. Applying electrokinetic process in natural soil has lower efficiency than artificial soil (Mena et al., 2012). The complexity of compounds possessed by natural soils make electrokinetic process more complicated (Boulakradeche et al., 2015). Soil permeability greatly affects the electrokinetic process. The lower the permeability of the 
soil, the greater the electroosmotic flow it was. The type of mineral is closely related to the surface area so it affects the total electrical charge per surface area (surface charge density). Large surface areas can provide larger amounts of negative surface and thus prolong the acidification time of soil due to electrokinetic processes. The order of soil mineral surface charge density from the largest to the smallest is as follows: montmorillonite > illite > kaolinite > silt > sand. Minerals can also experience negative charge deficiencies due to the presence of organic materials on the particle surface (Acar et al., 1995; Niqui-Arroyo et al., 2006; Wick et al., 2007; Yeung and Gu, 2011).

\subsection{Hydrocarbon contaminant}

Hydrocarbon compounds are hydrophobic and strongly bonded to soil minerals and other organic compounds in soil/sediment (Ammami et al., 2014). Most hydrocarbon compounds are non polar and neutral/uncharged, so electrokinetic processes have little effect on their movement in the pore fluid (Giannis et al., 2012). Petroleum hydrocarbons are part of a very complex organic compound and comprise into 4 parts: alkanes, aromatics, resins and asphaltenes. Alkanes have non-polar properties and are difficult to migrate under weak electric field, whereas resins and asphaltenes are polar but have long carbon chains, very strong bonds with soil particles and very difficult to migrate under electric field ( $\mathrm{Li}$ et al., 2010). Electrokinetic bioremediation has been proven to be used to treat a wide variety of hydrocarbon contaminants, including: polycyclic aromatic hydrocarbons (Lin et al., 2016; Mokhtarani et al., 2016; Wang et al., 2016; Xu et al., 2010), diesel oil (Lee et al., 2012; Mena et al., 2016c), total petroleum hydrocarbon (Dong et al., 2013; Fan et al., 2015), pyrene (Li et al., 2016), oxyfluorfen (Barba et al., 2017; Risco et al., 2016), and many more. In contrast to other hydrocarbon compounds, BTEX and TCE have large water solubility so they will be easily dissolved in pore fluid (Giannis et al., 2012; Park et al., 2007; Wu et al., 2012).

Fan et al. (2013) reported that electrokinetic bioremediation has a different response to petroleum hydrocarbon compounds. The degradation of n-alkanes is more due to the electrokinetic activity whereas the degradation of aromatic compounds is more due to biodegradation process. When a weak electric field applied in soil, electrokinetic phenomena become more dominant than bioremediation process and vice versa. The degradation of saturated alkane hydrocarbon compounds caused by electrochemical oxidation in soil matrix. When an electric current is applied, the clay particles become microconductor, where the oxidation reaction of hydrocarbons can take place. This oxidation activity is highly dependent on water content, $\mathrm{pH}$, electric intensity, and current. The electric intensity can extend the reaction zone of the degradation of hydrocarbon compounds (Fan et al., 2015; Li et al., 2010). In the absence of solubilizing agent, electrooxidation 
is a major phenomenon that can degrade and remove hydrocarbon compounds from soil particle (Harbottle et al., 2009; Ramirez et al., 2015).

The hydrocarbon compounds in pesticides can be well exposed in the area near anode when anionic surfactant (SDS) is used as an electrolyte, whereas the non-ionic surfactant is more effective at setting aside the hydrocarbons in the area near the cathode (Barba et al., 2017; Boulakradeche et al., 2015; Maturi and Reddy, 2009; Risco et al., 2016). The EKSF efficiency itself heavily depends on the chemical characteristics of pesticides to be set aside. The number of pesticides collected in the anode is more than the cathode. This finding shows that electrophoresis/electromigration phenomenon is more dominant in removing pesticides and distributing surfactant better in a short period of time (Barba et al., 2018). Electrokinetic soil flushing (using SDS) efficiently eliminates non-polar pesticides (atrazine and oxyfluorfen) by $80 \%$ and 2,4-D by $96 \%$ where volatilization is also known to be quite influential in the process. Chlorosulfuron is the most difficult compound to be removed by this technology (Vieira dos Santos et al., 2016). Calcium dodecylbenzenesulfonate (CDBS) is used as an oxyfluorfen solvent and micelles former. Electrodes are arranged in linear rows to increase dispersion and pollutant removal on the pilot scale. A total of $26.88 \%$ of oxyfluorfen can be removed with the existing electrode configuration. Electrophoresis plays an important role in carrying $18.7 \%$ 2,4-D to the anode and electroosmosis dragging $19.25 \%$ of oxyfluorfen to the cathode (Risco et al., 2016).

\subsection{Electrokinetic system and configuration}

Several strategies to improve electrokinetic bioremediation have been conducted by many researchers. Non-uniform electric current, for example, is used to increase the amount and distribution of bacteria in soil and increase the desorption and movement of hydrocarbon compounds in the EKSF-Bio system. Bacteria can move at a rate of $0.125-0.15 \mathrm{~cm}^{2} \mathrm{v}^{-1} \mathrm{~h}^{-1}$ under uniform conditions and $0.18-0.2 \mathrm{~cm}^{2} \mathrm{v}^{-1} \mathrm{~h}^{-1}$ under non-uniform conditions. In the uniform system, hydrocarbons move and accumulate in specific areas so biodegradation process is inhibited by high concentration of contaminant ( $\mathrm{Li}$ et al., 2012a; Li et al., 2013; Khodadadi et al., 2011). This problems can be solved by non-uniform electric current. Non-uniform vertical configuration system can be an alternatives for removing heavy metals and hydrocarbon from soil particle (Giannis et al., 2012; Wang et al., 2007).

The main critical factor in electrokinetic soil flushing - bioremediation is how to maintain $\mathrm{pH}$ neutrality. Controlling $\mathrm{pH}$ is necessary to prevent precipitation of heavy metals around the electrolyte chambers. Kim et al. (2005) used a modified electrolyte circulation method by mixing 
anolyte and catholyte. The research results showed that the pentadecane removal was $77.6 \%$ for 14 days. Xu et al. (2010) reported that an electrolyte circulation less than $800 \mathrm{ml} / \mathrm{h}$ cannot control the $\mathrm{pH}$ fluctuations well. The buffer solution can also be used as a control $\mathrm{pH}$ although it is not effectively used for long periods of time (Kim et al., 2010; Park et al., 2007; Pazos et al., 2011). Reversing polarity is the most effective way to keep $\mathrm{pH}$, temperature, and humidity stay at suitable range for EKSF-Bio processes (Fan et al., 2015; Ramirez et al., 2015). In addition, polarity reversal also consumes less energy than other techniques (Ammami et al., 2015). Polarity reversal period varies on a wide range of study: polarity changes every 5 minutes (Fan et al., 2015), 1 hour (Khodadadi et al., 2011), 12 hour (Li et al., 2012b; Xu et al., 2010), and 24 hour (Ramirez et al., 2015). Finding the appropriate period to reverse the polarity is a key factor that has to be consider when using this technique. However, polarity reversal cannot keep the $\mathrm{pH}$ in electrode chambers at certain time ranges so that low-pH environments can be found on soil near the electrode. The integration between polarity reversal and electrolyte circulation can solve these problems (Xu et al., 2010). The on-off method over a certain period of time is also claimed to increase the efficiency of hydrocarbon compounds removal. Hassan and his research team reported that the use of anodecathode configuration in one compartment (ACC) can maintain a good $\mathrm{pH}$ and nitrate concentration in every part of soil (Hassan et al., 2016b).

When EKSF-Bio applied in the field, electrode configuration is important factor that has to be determined (Perez-Corona et al., 2013). There are many researcher that working on onedimensional configuration, either vertical or horizontal. However, only limited research that studied about two-dimensional configuration. The examples of two-dimensional configuration are hexagonal, square, and triangular configuration (Barba et al., 2018; Kim et al., 2013). Onedimensional configuration is not practical to use in the field since a half of the total area is ineffective for electrokinetic reaction (dead zones). This limitation can be solved by using polarity reversal technique or applying non-uniform electric field. Two-dimensional configuration can create a non-linear electric field which ensure the distribution of nutrient, $\mathrm{pH}$, temperature and other environmental factor of EKSF-Bio (Alshawabkeh et al., 1999; Kim et al., 2013; Li et al., 2010; Perez-Corona et al., 2013). Li et al. (2010) used a square 2-D configuration to remove alkane from soil. The result showed that symmetrical electric field caused by square 2-D configuration can made electric intensity distributed effectively in the soil. Therefore, activities of bacteria can be accelerated and resulting a better degradation of alkane. In the other hand, Barba et al. (2018) using a hexagonal configuration which consist of 6 electrode and 1 biobarrier of activated sludge in the center of the pilot scale system. After run for 1 month, only few contribution of degradation in the electrokinetic system which is about $3.0 \%$ for $2,4-\mathrm{D}$ and $3.81 \%$ for oxyfluorfen. This opposite 
finding showed that the 2-D configuration can possibly give negative effect to the microorganism. Another strategy should be considered to cover this limitations.

On a pilot and field scale, large electrical intensity causes high temperatures in the system which then leads to massive water shortage and ohmic resistance. This situation also causes a major obstacle to electroosmosis. The accumulated nutrients in the electrodes have a detrimental effect on the viability of microorganisms. Nutrients, such as ammonium, sulfate and phosphate are concentrated and precipitated in the area near electrode due to electromigration, which then causing nutrient deficiency in the biobarrier. Microorganisms are only found in the middle (biobarrier) because the environmental condition (temperature, nutrient, and $\mathrm{pH}$ ) still support viability of microorganism (Barba et al., 2018; Li et al., 2012a; Li et al., 2013).

\subsection{Surface charge of surfactant}

Surfactant has been used by many researchers as electrolyte of EKSF-Bio for removing hydrocarbon contaminant from soil particle. Some aspects that has to be considered are (1) contaminant solubilization ability of surfactant in water, (2) desorption of contaminant form soil particle, (3) adsorption loss of surfactants, and (4) ecotoxicities of the surfactant. Solubilization ability is related to the CMC value of surfactants. Aqueous solubility of contaminant will decrease as the surfactant concentration is below CMC and vice versa. Non-ionic surfactants tend to have low CMC values so their contaminant solubilization ability will increase at low surfactant concentrations. In a previous study conducted by Guo et al., (2013) Langmuir (Qo) and Freundlich $\left(K_{f}\right)$ coefficient values in adsoption, shows that nonionic surfactant is more easily adsorbed by surface soil particles than anionic surfactant. The CMC value is also closely related to the desorption ability of contaminants from soil particles. It can be argued that the contaminant desorption ability is positively correlated to the improvement of solubilization contaminant ability. The ecotoxicities is very important in EKSF-Bio since biological activity may be lowered by the presence of toxic surfactants in the soil. Anionic surfactants except biosurfactants are known to be more toxic when compared with nonionic surfactant (Fan et al., 2013; Guo et al., 2013; Maturi et al., 2009).

Surfactants that are used in electrokinetic soil flushing and bioremediation (EKSF-Bio) are mostly derived from anionic (include biosurfactant) and nonionic surfactant (Ammami et al., 2015; Mena et al., 2016c). The anionic surfactant (-) is preferably compared to cationic surfactant (+) since most clay minerals have negative charge that are not potentially adsorbed into the soil particles surface (Ammami et al., 2014; Boulakradeche et al., 2015). Anionic surfactants have very low affinity to be 
adsorbed into soil/sediment but they are not economical because they tend to have a large value of critical micelle concentration (CMC) (Mena et al., 2016c). Non-ionic surfactants such as Tween 80 and Triton X-100 are often used because of their low toxicity, a good hydrocarbon compounds solvent, relatively low CMC, the potential is absorbed into low soil particles and is easily degraded by microorganism (Cheng et al., 2017; Pazos et al., 2011). In the recent study conducted by Wan et al. (2010), Triton X-100 (TX100) integrated with permeable reactive barrier is able to remediate $64.2 \%$ of hexachlorobenzene (HCB) in polluted soil. Ammami et al. (2015) found that the use of biosurfactants and Tween 20 can effectively clean the marine sediments from PAH. Sodium dodecyl sulfate (SDS) combined with biobarrier was able to remediate diesel oil contaminated soil by $29.10 \%$ in 14 days treatment (Mena et al., 2012).

In theory, anionic surfactants such as SDS, tend to move against electroosmosis direction (Ramírez et al., 2015). However, this is in contrast to the research conducted by Boulakradeche et al. (2015) where no hydrocarbon compounds are found in the anode chamber. This may occur because electroosmotic flow is stronger than charged colloid migration. Similar result has been showed in the previous research in which anionic surfactant transport has the same flow as electroosmotic flow, so that more hydrocarbon compounds are found in the cathode chamber. In short, the ability of surfactant to remove hydrocarbon contaminant in soil is as follows: anionic > nonionic > biosurfactant > cationic (Boulakradeche et al., 2015; Mena et al., 2015; Saichek and Reddy, 2005; Yang et al., 2005).

Fan et al. (2013) compared anionic - SDBS, nonionic - Brij 35 and biosurfactants - rhamnolipid to increase solubilization and remove PCBs from soil particles. In contrast with research conducted by Tao and Chengxun (2016), SDBS in Fan et al. (2013) did not provide significant results in all tests. Surfactants were also used to cover nanoparticles sterically and increase electrostatic resistance between particles so nanoparticle suspension will be stabilized. Nanoparticles are easy to form into aggregates because of Van der Waals forces and strong magnetic binding forces, thus reducing the transportability in the soil pores. PCBs can be removed well when using nano Pd / Brij 35 - xanthan gum combination resulting an average removal of more than 50\% (Fan et al., 2013). Brij 35 has an opportunity to increase PCB concentration retained in soil particles because of the effects of electrostatic appeal. Surfactants are known to improve EK + nano technology to remediate hydrocarbon contaminated soil (Alcántara et al., 2012; Fan et al., 2013; Shi et al., 2008). Park et al. (2007) explains that APG (alkyl polyglucoside) showing a great potential to remove hydrocarbon organic contaminant compared to Brij 30 and SDS, which is $65 \%$ from initial concentration. Brij 30 has a lower CMC than others so a high rate of removal at low concentration of surfactant can be 
expected. Buffers that often used in many researches are sodium chloride and acetate. Apparent charge density of SDS and another anionic surfactant decrease under low pH, so SDS micelles in anode would be transported to cathode (Park et al., 2007).

Maturi and Reddy (2009) remediate soil contaminated with mixed contaminant (heavy metals and PAHs) using surfactants enhanced electrokinetics. Igepal CA-720 and Tween 80 are compared and placed in anode chamber with 5 day on and 2 days off scheme. Current electricity in Igepal CA-720 is smaller than Tween 80 because of dielectric constant difference in each surfactant (Huang et al., 2012). The cumulative electroosmosis of deionized water is lower than both surfactants. Contaminant removal depends on the solution properties, dielectric constant, and viscosity (Mena et al., 2016a; Shi et al., 2008). At low pH, only a small amount of surfactant is available to dissolve phenanthrene, the oxyethylene group on Tween 80 may be attached to the surface of the soil particles (Maturi and Reddy, 2009).

Many studies has been conducted to find the most effective type of surfactant in electrokinetic bioremediation treating hydrocarbon contaminant. Mixed surfactants can be used to effectively remove PCBs. A mixture of Tween 80 and SDBS (3:2) can increase the desorption process by up to $64.58 \%$ at a voltage gradient of $1.5 \mathrm{~V} / \mathrm{cm}$ for 10 days which is 1.57 times greater than without electrokinetic. The more SDBS mixed with Tween 80, the less Tween 80 adsorbed to soil particles so that the contaminant solubilization process becomes more effective. The use of mixed surfactants may prevent further contamination due to the accumulation of surfactant adsorption in the surface of soil particles (Tao and Chengxun, 2016). Table 2 shows various studies of electrokinetic soil flushing and bioremediation in different flushing fluid/surfactant for removing hydrocarbon contaminant. 
Table 2

Studies on electrokinetic soil flushing and bioremediation in treating hydrocarbon contaminated soil.

\begin{tabular}{|c|c|c|c|c|c|c|c|c|c|}
\hline No & $\begin{array}{l}\text { Electrokinetic } \\
\text { reactor }\end{array}$ & $\begin{array}{l}\text { Surfactant / } \\
\text { flushing fluid }\end{array}$ & Soil type & $\begin{array}{l}\text { Type of } \\
\text { surfactant }\end{array}$ & $\begin{array}{l}\text { Substrate / } \\
\text { contaminant }\end{array}$ & Culture & Duration & $\begin{array}{l}\text { Highest } \\
\text { removal } \\
\text { efficiency }\end{array}$ & Reference \\
\hline 1 & $\begin{array}{l}\text { Soil column / } \\
\text { EK-Bio }\end{array}$ & Brij35 & Clay silt & Nonionic & $\begin{array}{l}\text { Polycyclic } \\
\text { aromatic } \\
\text { hydrocarbon } \\
\text { (PAHs) }\end{array}$ & $\begin{array}{l}\text { PAH-degrading } \\
\text { bacteria (Sphingomonas } \\
s p . \text { L138 and } M . \\
\text { Frederiksbergense } \\
\text { LB501TG) }\end{array}$ & $\begin{array}{l}6-24 \\
\text { hours }\end{array}$ & Up to $80 \%$ & $\begin{array}{l}\text { Wick et al., } \\
2004\end{array}$ \\
\hline 2 & $\begin{array}{l}\text { Soil column / } \\
\text { EK-Bio }\end{array}$ & $\begin{array}{l}\text { Tween } 80 \text { and } \\
\text { EDTA }\end{array}$ & $\begin{array}{l}\text { Loamy } \\
\text { sand }\end{array}$ & Nonionic & $\begin{array}{l}\text { Lead }(\mathrm{Pb}) \text { and } \\
\text { total petroleum } \\
\text { hydrocarbon } \\
(\mathrm{TPH})\end{array}$ & $\begin{array}{l}\text { Microorganism } \\
\text { indigenous }\end{array}$ & 30 days & $\begin{array}{l}\mathrm{Pb} 81.7 \% \text { and } \\
\mathrm{TPH} 88.3 \%\end{array}$ & $\begin{array}{l}\text { Dong et al., } \\
2013\end{array}$ \\
\hline 3 & $\begin{array}{l}\text { Soil column } \\
\text { with } \\
\text { bioreactor }\end{array}$ & biosurfactant & - & Biosurfactant & Disulfide oil & Bacillus subtilis & 5 days & $67 \%$ & $\begin{array}{l}\text { Asgari et al., } \\
2013\end{array}$ \\
\hline 4 & $\begin{array}{l}\text { Soil column / } \\
\text { EK-Bio }\end{array}$ & $\begin{array}{l}\text { Citric acid, } \\
\text { tween } 20, \\
\text { rhamnolipid }\end{array}$ & $\begin{array}{l}\text { Dredged } \\
\text { sediment, } \\
\text { silt }\end{array}$ & $\begin{array}{l}\text { Nonionic, } \\
\text { anionic, } \\
\text { biosurfactant }\end{array}$ & $\begin{array}{l}\text { Polycyclic } \\
\text { aromatic } \\
\text { hydrocarbon }\end{array}$ & - & $\begin{array}{l}21-50 \\
\text { days }\end{array}$ & $54.4 \%$ & $\begin{array}{l}\text { Ammami et } \\
\text { al., } 2013\end{array}$ \\
\hline 5 & $\begin{array}{l}\text { EKSF + nano } \\
\text { technology } \\
\text { (Batch and EK } \\
\text { Test) }\end{array}$ & $\begin{array}{l}\text { SDBS, Brij35, } \\
\text { Biosurfactant, } \\
\text { Xanthan gum }\end{array}$ & $\begin{array}{l}\text { Fine- } \\
\text { grained soil }\end{array}$ & $\begin{array}{l}\text { Anionic, } \\
\text { nonionic dan } \\
\text { biosurfactant }\end{array}$ & $\begin{array}{l}\text { Polychlorinated } \\
\text { Biphenyls } \\
\text { (PCBs) }\end{array}$ & - & 8 days & $20 \%$ & $\begin{array}{l}\text { Fan et al., } \\
2013\end{array}$ \\
\hline 6 & EKSF & $\begin{array}{l}\text { Nitric acid } \\
\text { (NA), citric } \\
\text { acid (CA), } \\
\text { Sodium } \\
\text { dodecyl sulfate }\end{array}$ & $\begin{array}{l}\text { Fine- } \\
\text { grained } \\
\text { sediment }\end{array}$ & $\begin{array}{l}\text { Anionic and } \\
\text { nonionic }\end{array}$ & $\begin{array}{l}\text { Polycyclic } \\
\text { aromatic } \\
\text { hydrocarbons } \\
\text { (PAHs) and } \\
\text { metals }\end{array}$ & - & $\begin{array}{l}10-14 \\
\text { days }\end{array}$ & $\begin{array}{l}\text { NA can } \\
\text { remove } \\
\text { metals } 76.8- \\
99.9 \% \text { and } \\
\text { PAHs } 70.3-\end{array}$ & $\begin{array}{l}\text { Ammami et } \\
\text { al., } 2014\end{array}$ \\
\hline
\end{tabular}




\begin{tabular}{|c|c|c|c|c|c|c|c|c|c|}
\hline No & $\begin{array}{l}\text { Electrokinetic } \\
\text { reactor }\end{array}$ & $\begin{array}{l}\text { Surfactant / } \\
\text { flushing fluid }\end{array}$ & Soil type & $\begin{array}{l}\text { Type of } \\
\text { surfactant }\end{array}$ & $\begin{array}{l}\text { Substrate / } \\
\text { contaminant }\end{array}$ & Culture & Duration & $\begin{array}{l}\text { Highest } \\
\text { removal } \\
\text { efficiency }\end{array}$ & Reference \\
\hline & & $\begin{array}{l}\text { (SDS), Tween } \\
20\end{array}$ & & & & & & $89.7 \%$ & \\
\hline 7 & EKSF-Bio & $\begin{array}{l}\text { Sodium } \\
\text { dodecyl sulfate } \\
\text { (SDS) }\end{array}$ & Kaolinite & Anionic & Diesel oil & $\begin{array}{l}\text { Diesel degrading } \\
\text { consortium }\end{array}$ & 2 weeks & $29 \%$ & $\begin{array}{l}\text { Ramirez et al., } \\
2015\end{array}$ \\
\hline 8 & EKSF & $\begin{array}{l}\text { Tween80, triton } \\
\text { X-100, SDS }\end{array}$ & & $\begin{array}{l}\text { Anionic, } \\
\text { nonionic }\end{array}$ & $\begin{array}{l}\text { Polycyclic } \\
\text { aromatic } \\
\text { hydrocarbons } \\
\text { (PAHs) and } \\
\text { aliphatic } \\
\text { hydrocarbons }\end{array}$ & - & 10 days & $\begin{array}{l}69 \% \text { of n- } \\
\text { hexadecane } \\
\text { and } 59 \% \\
\text { anthracene }\end{array}$ & $\begin{array}{l}\text { Boulakradeche } \\
\text { et al., } 2015\end{array}$ \\
\hline 9 & $\begin{array}{l}\text { EKSF-Bio, } \\
\text { soil column }\end{array}$ & Biosurfactant & - & $\begin{array}{l}\text { Anionic, } \\
\text { biosurfactant }\end{array}$ & Phenanthrene & $\begin{array}{l}\text { Phe-degrading } \\
\text { Sphingomonas sp. } \\
\text { GY2B }\end{array}$ & 5 days & $\begin{array}{l}49,9 \% \\
\text { (Cathode) - } \\
65,1 \% \\
\text { (Anode) }\end{array}$ & $\begin{array}{l}\text { Lin et al., } \\
2015\end{array}$ \\
\hline 10 & $\begin{array}{l}\text { EKSF Bio- } \\
\text { PRBs }\end{array}$ & $\begin{array}{l}\text { Sodium } \\
\text { dodecyl sulfate } \\
\text { (SDS) }\end{array}$ & Kaolinite & Anionic & Diesel oil & $\begin{array}{l}\text { Diesel degrading } \\
\text { consortium }\end{array}$ & 2 weeks & $30 \%$ & $\begin{array}{l}\text { Mena et al., } \\
2015\end{array}$ \\
\hline 11 & EKSF & $\begin{array}{l}\text { Calcium } \\
\text { dodecylbencene } \\
\text { sulfonate } \\
\text { (CDBS) }\end{array}$ & Silty loam & Anionic & $\begin{array}{l}\text { Oxyfluorfen } \\
\text { and } 2,4 \mathrm{D}\end{array}$ & - & 34 days & $\begin{array}{l}26,8 \% \text { of } \\
\text { oxyfluorfen }\end{array}$ & $\begin{array}{l}\text { Risco et al., } \\
2016\end{array}$ \\
\hline 12 & $\begin{array}{l}\text { EKSF } \\
\text { Biobarrier }\end{array}$ & $\begin{array}{l}\text { Sodium } \\
\text { dodecyl sulfate } \\
\text { (SDS) }\end{array}$ & Kaolinite & Anionic & Diesel oil & $\begin{array}{l}\text { Diesel degrading } \\
\text { consortium (BB1) and } \\
\text { activated sludge from } \\
\text { municipal wastewater }\end{array}$ & 2 weeks & $\begin{array}{l}27,36 \% \text { in } \\
\text { BB1 and } \\
29,1 \% \mathrm{BB} 2\end{array}$ & $\begin{array}{l}\text { Mena et al., } \\
2016\end{array}$ \\
\hline
\end{tabular}




\begin{tabular}{|c|c|c|c|c|c|c|c|c|c|}
\hline No & $\begin{array}{l}\text { Electrokinetic } \\
\text { reactor }\end{array}$ & $\begin{array}{l}\text { Surfactant / } \\
\text { flushing fluid }\end{array}$ & Soil type & $\begin{array}{l}\text { Type of } \\
\text { surfactant }\end{array}$ & $\begin{array}{l}\text { Substrate / } \\
\text { contaminant }\end{array}$ & Culture & Duration & $\begin{array}{l}\text { Highest } \\
\text { removal } \\
\text { efficiency }\end{array}$ & Reference \\
\hline & & & & & & treatment (BB2) & & & \\
\hline 13 & $\begin{array}{l}\text { EKSF } \\
\text { biobarrier - } \\
\text { pilot scale }\end{array}$ & $\begin{array}{l}\text { Sodium } \\
\text { dodecyl sulfate } \\
\text { (SDS) }\end{array}$ & $\begin{array}{l}\text { Real natural } \\
\text { clay soil }\end{array}$ & Anionic & Diesel oil & $\begin{array}{l}\text { Diesel degrading } \\
\text { consortium }\end{array}$ & 4 weeks & $\begin{array}{l}\text { Less then } \\
10 \%\end{array}$ & $\begin{array}{l}\text { Mena et al., } \\
2016\end{array}$ \\
\hline 14 & EK-Bio & $\begin{array}{l}\text { Biosurfactant } \\
\text { from Bacillus } \\
\text { subtilis strains }\end{array}$ & - & Anionic & $\begin{array}{l}\text { Phenanthrene } \\
\text { and fluorene }\end{array}$ & $\begin{array}{l}\text { Bacillus subtilis DSMZ } \\
3256 \text { strains }\end{array}$ & 4 days & $39,4 \%$ & $\begin{array}{l}\text { Mokhtarani et } \\
\text { al., } 2016\end{array}$ \\
\hline 15 & EK-Bio & $\begin{array}{l}\text { Nutrient and } \\
\text { microorganism } \\
\text { injection }\end{array}$ & Sandy soil & - & $\begin{array}{l}\text { Polycyclic } \\
\text { aromatic } \\
\text { hydrocarbons } \\
\text { (PAHs) }\end{array}$ & L. theobromae & 200 days & $\begin{array}{l}50.6 \% \pm \\
4.3 \% \\
\text { to } 56.8 \% \pm \\
1.7 \%\end{array}$ & $\begin{array}{l}\text { Wang et al., } \\
2016\end{array}$ \\
\hline 16 & EK-Bio & - & Clayey soil & - & Pyrene & $\begin{array}{l}\text { Pyrene-degrading } \\
\text { microorganism }\end{array}$ & 42 days & $55.9 \%$ & Li et al., 2016 \\
\hline 17 & EK-Bio & $\begin{array}{l}\text { Calcium } \\
\text { dodecylbencene } \\
\text { sulfonate } \\
\text { (CDBS) }\end{array}$ & Clayey soil & anionic & Oxyfluorfen & $\begin{array}{l}\text { Oil refinery wastewater } \\
\text { treatment plant } \\
\text { microbial consortium }\end{array}$ & 2 weeks & $15 \%$ & $\begin{array}{l}\text { Barba et al., } \\
2017\end{array}$ \\
\hline 18 & EKSF-Bio & B-cyclodextrin & $\begin{array}{l}\text { Agricultural } \\
\text { soil }\end{array}$ & - & $\begin{array}{l}\text { Textile reactive } \\
\text { dye }\end{array}$ & $\begin{array}{l}\text { Pseudomonas } \\
\text { aeruginosa, } \\
\text { Brevibacterium } \\
\text { halotolerans, Bacillus } \\
\text { subtilis and } \\
\text { Achromobacter sp. }\end{array}$ & $\begin{array}{l}5-15 \\
\text { days }\end{array}$ & $\begin{array}{l}\text { From } 15.5 \\
\mathrm{dS} / \mathrm{m} \text { to } 1.5 \\
\mathrm{dS} / \mathrm{m} \\
\text { (conductivity) } \\
\text { Dye was } \\
\text { measured } \\
\text { using colour } \\
\text { spectrum }\end{array}$ & $\begin{array}{l}\text { Annamalai et } \\
\text { al., } 2017\end{array}$ \\
\hline
\end{tabular}




\subsection{Electrolyte characteristic}

Some researchers only use deionized water as an electrolyte in the removal of hydrocarbon compounds. This condition has been described by Wang et al. (2007) where the main removal mechanism of non-charged/neutral compounds such as hydrocarbons may occur as a result of uplifting effect and/or dielectrophoresis. Uplifting effect is a nonionic contaminant transport mechanism that is dragged in the same direction as the water flow within soil pores. Dielectrophoresis is a movement due to an electric dipole formed in a non-uniform electric field (Wang et al., 2007). Enhancing agents are indispensable for increasing the removal of organic and metal compounds where they are strongly bonded to clay particles. Previous research have reported that the use of surfactants mixed with chelating agents can increase electroosmotic rates (Kim et al., 2010). Chelating agents are very effective to remove metalic compounds and keep the $\mathrm{pH}$ neutral in the cathode chamber, whereas compounds such as surfactants and cyclodextrins are useful for solubilizing organic contaminants (Alcántara et al., 2012; Ammami et al., 2014). Fig. 3 illustrating some flushing fluid types that often used by many researchers for treating hydrocarbon contaminated soil using EKSF-Bio.

The use of chelating agents and surfactants mixture is known to increase the efficiency of hydrocarbon and heavy metals removal (Katz et al., 1997; Kim et al., 2010; Zhao et al., 2016). Hahladakis et al. (2014) using non-ionic innovative surfactants that never used before: Tween 80, Poloxamer 407 and Nonidet P40 are combined with citric acid to remove the PAHs compound from sediment (sandy soil). Acetic acid can also be used as a catholyte because most of metal acetates can be dissolved, have high biodegradability, and acetate ions can prevent the formation of insoluble salts at the cathode so prevent the increasing of electrical conductivity (EC) and increasing energy dissipation in soil near cathode (Hahladakis et al., 2014; Yeung and Gu, 2011). Nitric acid is best used together with surfactants as it increases $\mathrm{pH}$, supports the electroosmosis enhancement and enhances solubilization process and hydrocarbon oxidation. However, the combination of surfactant (nonionic) and citric acid is preferred for electrokinetic bioremediation because it is environmentally friendly and has considerable efficiency to remove hydrocarbons and heavy metals (Ammami et al., 2014; Boulakradeche et al., 2015; Lee et al., 2012). Biosurfactants (rhamnolipid and vicosin) are known to work well in removing polycyclic aromatic hydrocarbons (PAHs) and heavy metals when combined with citric acid (Ammami et al., 2014). Rhamnolipid has a greater electrical conductivity value but show smaller removal result than Tween 20. This may be happened because the possibility of micelle migration through electroosmosis is not significant in biosurfactants (Ammami et al., 2015; Boulakradeche et al., 2015). Tween 20 and ammonium citrate are combined to decrease the concentration of cadmium and copper in the soil. The use of 
ammonium citrate has an impact on zeta potential decreases thereby increasing cation removal (Paramkusam et al., 2015).

The surfactant has a hydrophobic and hydrophilic functional group so that the hydrocarbon compound can be solubilized in micelle form. Nevertheless, some researchers suggest that the use of saline solutions as macronutrients $\left(\mathrm{NaCl}, \mathrm{KCl}, \mathrm{NH}_{4}, \mathrm{Na}_{2} \mathrm{SO}_{4}, \mathrm{NaOH}\right)$, hydrogen peroxide, cosolvent (alcohol and EDTA) and chelating agents (citric and nitric acid) (60\%-95\%) in removing hydrocarbon compounds (Giannis et al., 2012; Kim et al., 2010; Vieira dos Santos et al., 2014). EDTA also has a significant impact on microbial activity, especially in the area near the cathode. EDTA is a complexing agent that can increase solubilization of hydrophobic contaminants but due to high alkalinity and toxicity, EDTA provides losses to microbial activities and communities in soil (Dong et al., 2013; Hahladakis et al., 2016; Kim et al., 2010). $\beta$-cyclodextrin contained in the starch is known to be used to improve the electrokinetic bioremediation process of contaminated soil. Cyclodextrin can efficiently dissolve organic contaminants in the form of reactive textile dye. With the help of cyclodextrin and bacteria, the concentration of COD decreases, the phosphorus content in the soil increases, and the electrical conductivity decreases to $2.0 \mathrm{dS} / \mathrm{m}$ so that the soil is well suited for agricultural activity (Annamalai et al., 2017).

Surfactants can also be combined with oxidants to remediate hydrocarbon compounds (Li et al., 2014; Tiehm et al., 2009; Zhao et al., 2016). Nonionic surfactant, Igepal CA-720 is used as a PCBs solubiliser can be combined with persulfate as a powerful oxidant $\left(\mathrm{E}^{0}=2.01 \mathrm{~V}\right)$ and able to react with various types of organic contaminants. Oxidants are transferred into soil using electromigration and electroosmosis process to improve the efficiency of organic pollutant removal in the soil. Oxidizing agent activity can be enhanced by providing high temperature, high $\mathrm{pH}$, chelates and zero valent iron (Mena et al., 2016c). Nevertheless, the use of zero valent iron (ZVI) as an activator is not effective enough in delivering persulfate to soil pores. Igepal CA-720 of $2 \%$ can increase solubilization of PCBs and bring it to cathode while persulfate is supplied to cathode due to electromigration. The greatest PCBs degradation occurred when using a combination of Igepal CA720 of $2 \%$ and sodium persulfate of $20 \%$ with degradation efficiency of $38 \%$ (Fan et al., 2014).

\subsection{Electrolyte viscosity}

When surfactant is used as processing fluid, electroosmotic rate will decrease as concentration increases. Therefore, an ionic species is needed to increase the electric field strength. Surfactant solution concentration and its acidity also affects the electroosmosis process. Although most of surfactants except cationic surfactant proved to be highly effective in treating hydrocarbons in 
homogeneous contaminated soil, surfactant concentrations needs to be determined early. The concentration must be large enough to form a micelles/above the $\mathrm{CMC}$ value. Meanwhile, the surfactant concentration should be as low as possible to prevent the decrease of electroosmotic flow due to the decrease of zeta potential and electro-oxidation/biodegradation competition between hydrocarbon and surfactant compounds (Ammami et al., 2014). The larger the surfactant concentration, the diffusion process of surfactant into the soil pores would be smaller. At acidic $\mathrm{pH}$, only a few surfactants are found to be dissolved in soil matrices (Maturi and Reddy, 2009).

$v_{E O F}=\frac{D \varepsilon_{o} \zeta}{\eta} E x$

According to Helmholtz theory that written in equation (3), Electroosmotic flow ( $\left.v_{\mathrm{EOF}}\right)$ is proportional to dielectric constant (D), vacuum permittivity $\left(\varepsilon_{0}\right)$, electric field $\left(E_{X}\right)$, and zeta potential $(\zeta)$ of a solution, but inversely proportional to its viscosity $(\eta)$. When using rhamnolipids, electroosmotic flow actually decreases because of the high viscosity of the solution (Ammami et al., 2015). Surfactants increase the viscosity of the solution leading to decrease of electroosmotic rate because of the high fluid resistance to flow within soil pores. However, at low surfactant concentrations $(<0.01 \mathrm{M}$ for SDS), there was no significant difference in electroosmotic flow. Anionic surfactant produces a more negative zeta potential and lowers the initial zeta potential which increasing the electroosmotic flow (Wick et al., 2007). Tween 80 activity is known to increase in low $\mathrm{pH}$ conditions (locations near the anode), whereas SDS is known to be quite effective when placed at cathode (Lin et al., 2016; Mena et al., 2015). Those finding can certainly explain the possible integration between the use of two different types of surfactants in both electrodes (Boulakradeche et al., 2015). The increased viscosity can lead to foaming after 60 hours of working on electrolyte so that the use of surfactants at higher concentration for nonionic surfactants (more than $5 \%$ ) is not recommended. As a result, there is a drastic reduction in current electricity due to the precipitation of non-conductive sediment particles and the unavailability of free-moving ions. The decrease in current electricity is always accompanied by a decrease in electroosmotic rate. PAHs percentage that can be removed by Poloxamer 407 and Nonidet P40 respectively by $43 \%$ and $48 \%$, is quite large when compared to other researches using different nonionic surfactants (Hahladakis et al., 2014).

\section{Challenges and perspective in the future}

SURF (Sustainable Remediation Forum) defines continuous remediation as remediation activities that can reduce global impacts, minimize the potential for atmospheric pollution and the safety of workers and communities and controlled/reduced the consumption of resources and energy. 
Basically, electrokinetic technology requires considerable water and electrical energy, but research developments suggests the sustainability potential of EKSF-Bio technology (Gill et al., 2015a; Lima et al., 2017). Based on the assessments made by previous researcher (by using the SURF-UK assesment tools), electrokinetic bioremediation is a kind of green technology which has the potential to be more environmentally friendly compared to others conventional technologies such as natural attenuation, air sparging/soil vapour extraction, and pump and treat to remediate contaminated soil. EK-Bio does not require further processing and removal of soil that requires substantial cost. However, EK-Bio assessment is based on pilot scale test because there is no full field-scale application to confirm the effectiveness of the process on larger scale. The use of solar panels and electrolyte recirculation can reduce operational costs and $\mathrm{pH}$ and corrosion changes in the EKSF-Bio electrode. Furthermore, the research on how to make an appropriate and efficient processing designs are needed to make this technology more sustainable (Annamalai et al., 2017; Gill et al., 2015a; Yan and Reible, 2015).

Bioremediation in low permeability soil is possible. However, bioremediation itself needs a long period of processing time (about 2-3 months) and requires favourable environmental condition, low bioavailability and bioaccessible of contaminant. More research and innovation is required to improve the efficiency of the operational process, especially on 2-dimensional electrode configuration for practical application. According to Perez-Corona et al. (2013), there are several things to consider in scaling up process design from laboratory to field/pilot scale: soil area and volume, electrode spacing and height, extrapolation of electric field in laboratory scale and laboratory cell current density (to estimate required current in pilot scale). There are several other technical considerations to be highlighted: fluctuations in concentrations occurring in the area around the electrode, the geophysical properties of the location to be used for research and the presence of dead zone phenomena (the zones where microorganisms experience significant decay due to electrokinetic phenomena). Concentration of fluctuations and dead zones are two interrelated issues where these problems can be solved by using the concept of polarity reversal and on-off system (Barba et al., 2017; Li et al., 2015). The optimum concentration of surfactant in treating contaminated soil also needs to be known and adapted to the field application. Research in pilot and field scale has been conducted by Ramirez et al (2016). However, there has not been many research conducted in tropical climate since climate is related to the temperature. It may be important when this technology will be applied in the field which is hard to control the surrounding temperature. The differentiation of temperature would give a different operational condition. 
As the amount of treated soil increases, its energy consumption will increase. This is due to the increasing amount of voltage and electrode spacing. The limitation of primary energy sources such as coal and grid becomes important to be addressed. Some technologies such as solar panels, wind energy and microbial fuel cells can be used as an alternative energy source (Gill et al., 2014; Hassan et al., 2016b; Habibul et al., 2016; Souza et al., 2016; Yan and Reible, 2015). Habibul et al. (2016) stated that microbial fuel cells (MFCs) can efficiently drive sustainable electrokinetic remediation to remove $\mathrm{Cd}$ and $\mathrm{Pb}$ within 100 days of operation. This long operation time occurs because electrokinetic remediation requires electric current more than MFCs can provide. Nevertheless, MFCs is potentially to be used as an alternative energy source for electrokinetic remediation because it can provide direct electriity generation from metabolism activity of microorganism (Habibul et al., 2016). Wind energy is also known to be used as an energy source of electrokinetic remediation to remove 2.4-D from the soil. This technology is quite attractive because it is environmentally friendly and can be used in remote locations (Souza et al., 2016). Solar panels are known to be more desirable than other alternatives because they produce electricity in nearly zero pollution, low maintenance costs and long time operation (Hassan et al., 2015; Yan and Reible, 2015). Solar panels and winds technology require batteries because in the calm conditions (without wind source) or lack of sunlight (night / cloudy), energy is necessary for electrokinetic process sustainability. If electrokinetic cannot be continuously supported by electricity, the process would be inefficient to remove contaminants (Souza et al., 2016). Choosing the appropriate alternative energy source should be determined when working in a remote areas.

\section{Conclusions}

Electrokinetic soil flushing and bioremediation (EKSF-Bio) is an innovative and promising technology for treating hydrocarbon contaminated soil. However, research and practical application of EKSF-Bio is still hard to be found. A comprehensive review about fundamental interaction of electrokinetic, enhancing solution, and bioremediation is provided in this paper. Recent progress and development of EKSF-Bio are given to the reader for future development of this technology. This paper gives a summary of sustainability assesment, principal factor and also provides challenges and perspective of EKSF-Bio to the reader who interested in developing EKSF-Bio as sustainable remediation technology in the future.

\section{Acknowledgement}

The researcher would like to thank to LPDP as institution that financed this research and also Department of Environmental Engineering, ITB that give many support to researchers. 


\section{References}

Acar, Y.B., Gale, R.J., Alshawabkeh, A.N., Marks, R.E., Puppala, S., Bricka, M., Parker, R., 1995. Electrokinetic remediation: basics and technology status. J. Hazard. Mater. 40, 117-137. https://doi.org/10.1016/0304-3894(94)00066-P

Alcántara, M.T., Gómez, J., Pazos, M., Sanromán, M.A., 2012. Electrokinetic remediation of lead and phenanthrene polluted soils. Geoderma 173-174, 128-133. https://doi.org/10.1016/j.geoderma.2011.12.009

Alshawabkeh, A.N., Gale R.J., Ozsu-Acar, E., Bricka, M., 1999. Optimization of 2-D Electrode Configuration for Electrokinetic Remediation. J. Soil. Contamination 8, 617-635.

Ammami, M.T., Benamar, A., Wang, H., Bailleul, C., Legras, M., Le Derf, F., Portet-Koltalo, F., 2014. Simultaneous electrokinetic removal of polycyclic aromatic hydrocarbons and metals from a sediment using mixed enhancing agents. Int. J. Environ. Sci. Technol. 11, 1801-1816. https://doi.org/10.1007/s13762-013-0395-9

Ammami, M.T., Portet-Koltalo, F., Benamar, A., Duclairoir-Poc, C., Wang, H., Le Derf, F., 2015. Application of biosurfactants and periodic voltage gradient for enhanced electrokinetic remediation of metals and PAHs in dredged marine sediments. Chemosphere 125, 1-8. https://doi.org/10.1016/j.chemosphere.2014.12.087

Annamalai, S., Santhanam, M., Selvaraj, S., Sundaram, M., Pandian, K., Pazos, M., 2017. Green technology: bio-stimulation by an electric field for textile reactive dye contaminated agricultural soil. Sci. Total Environ. 624, 1649-1657. https://doi.org/10.1016/j.scitotenv.2017.10.047

Asgari, M., Mokhtarani, B., Ataei, A., Heidar, K.T., 2013. Effect of electrokinetic on bioremediation of disulfide oil contaminated soil. J. Oil, Gas, and Petrochem. Technol. 1, 45-56.

Azhar, A., Nabila, A., Shaylinda, M., Azim, M., 2016. Electromigration of contaminated soil by electro- bioremediation technique, in: Materials Science and Engineering. IOP Conf. Series, pp. 1-6. https://doi.org/10.1088/1757-899X/136/1/012023

Barba, S., López-Vizcaíno, R., Saez, C., Villaseñor, J., Cañizares, P., Navarro, V., Rodrigo, M.A., 2018. Electro-bioremediation at the prototype scale: what it should be learned for the scale-up. Chem. Eng. J. 334, 2030-2038. https://doi.org/10.1016/j.cej.2017.11.172

Barba, S., Villaseñor, J., Rodrigo, M.A., Cañizares, P., 2017. Effect of the polarity reversal frequency in the electrokinetic-biological remediation of oxyfluorfen polluted soil. Chemosphere 177, 120-127. https://doi.org/10.1016/j.chemosphere.2017.03.002 
Boulakradeche, M.O., Akretche, D.E., Cameselle, C., Hamidi, N., 2015. Enhanced electrokinetic remediation of hydrophobic non-ionic and ionic surfactants. Electrochim. Acta 174, 10571066. https://doi.org/10.1016/j.electacta.2015.06.091

Cameselle, C., Chirakkara, R.A., Reddy, K.R., 2013. Electrokinetic-enhanced phytoremediation of soils : status and opportunities. Chemosphere 93, 626-636. https://doi.org/10.1016/j.chemosphere.2013.06.029

Cameselle, C., 2015. Enhancement Of Electro-Osmotic Flow During The Electrokinetic Treatment Of A Contaminated Soil. Electrochim. Acta 181, 31-38. https://doi.org/10.1016/j.electacta.2015.02.191.

Chen, T., Sun, C., 2016. Polychlorinated biphenyls-contaminated soil washing with mixed surfactants enhanced by electrokinetics. Chem. Res. Chinese Univ. 32, 261-267. https://doi.org/10.1007/s40242-016-5369-2

Cheng, M., Zeng, G., Huang, D., Yang, C., Lai, C., Zhang, C., Liu, Y., 2017. Advantages and challenges of Tween 80 surfactant-enhanced technologies for the remediation of soils contaminated with hydrophobic organic compounds. Chem. Eng. J. 314, 98-113. https://doi.org/10.1016/j.cej.2016.12.135

Choi, J.-H., Maruthamuthu, S., Lee, H.-G., Ha, T.-H., Bae, J.-H., 2009. Nitrate removal by electrobioremediation technology in Korean soil. J. Hazard. Mater. 168, 1208-1216. https://doi.org/10.1016/j.jhazmat.2009.02.162

Da Rocha, U.N., Totola, M.R., Pessoa, D.M.M., Araruna Jr., J.T., Neves, J.C.L., Borges, A.C., 2009. Mobilisation of bacteria in a fine-grained residual soil by electrophoresis. J. Hazard. Mater. 161, 485-491. https://doi.org/10.1016/j.jhazmat.2008.04.022

Dong, Z.-Y., Huang, W.-H., Xing, D.-F., Zhang, H.-F., 2013. Remediation of soil co-contaminated with petroleum and heavy metals by the integration of electrokinetics and biostimulation. $\mathrm{J}$. Hazard. Mater. 260, 399-408. https://doi.org/10.1016/j.jhazmat.2013.05.003

Fan, G., Cang, L., Fang, G., Zhou, D., 2014. Surfactant and oxidant enhanced electrokinetic remediation of a PCBs polluted soil. Sep. Purif. Technol. 123, 106-113. https://doi.org/10.1016/j.seppur.2013.12.035

Fan, G., Cang, L., Qin, W., Zhou, C., Gomes, H.I., Zhou, D., 2013. Surfactants-enhanced electrokinetic transport of xanthan gum stabilized nanoPd/Fe for the remediation of PCBs $\begin{array}{llllll}\text { contaminated } & \text { soils. } & \text { Sep. }\end{array}$ https://doi.org/10.1016/j.seppur.2013.04.030

Fan, R., Guo, S., Li, T., Li, F., Yang, X., Wu, B., 2015. Contributions of electrokinetics and bioremediation in the treatment of different petroleum components. Clean - Soil. Air. Water 43, 251-259. https://doi.org/10.1002/clen.201300659 
Giannis, A., Tay, E., Kao, J., Wang, J.Y., 2012. Impact of vertical electrokinetic-flushing technology to remove heavy metals and polycyclic aromatic hydrocarbons from $\begin{array}{lllll}\text { contaminated } & \text { soil. } & \text { Electrochim. } & \text { Acta } & \text { 86, }\end{array}$ https://doi.org/10.1016/j.electacta.2012.04.034

Gill, R.T., Harbottle, M.J., Smith, J.W.N., Thornton, S.F., 2014. Electrokinetic-enhanced bioremediation of organic contaminants: a review of processes and environmental applications. Chemosphere 107, 31-42. https://doi.org/10.1016/j.chemosphere.2014.03.019

Gill, R.T., Thornton, S.F., Harbottle, M.J., Smith, J.W.N., 2015a. Sustainability assessment of electrokinetic bioremediation compared with alternative remediation options for a petroleum release site. J. Environ. Manage. 184, 120-131. https://doi.org/10.1016/j.jenvman.2016.07.036

Gill, R.T., Thornton, S.F., Harbottle, M.J., Smith, J.W.N., 2015b. Electrokinetic migration of nitrate through heterogeneous granular porous media. Groundw. Monit. Remediat. 35, 46-56. https://doi.org/10.1111/gwmr.12107

Guo, P., Chen, W., Li, Y., Chen, T., Li, L., Wang, G., 2013. Selection of surfactant in remediation of DDT-contaminated soil by comparison of surfactant effectiveness. Environ. Sci. Pollut. Res. 21, 1370-1379. https://doi.org/10.1007/s11356-013-1993-2

Guo, S., Fan, R., Li, T., Hartog, N., Li, F., Yang, X., 2014. Synergistic effects of bioremediation and electrokinetics in the remediation of petroleum-contaminated soil. Chemosphere 109, 226-233. https://doi.org/10.1016/j.chemosphere.2014.02.007

Hahladakis, J.N., Latsos, A., Gidarakos, E., 2016. Performance of electroremediation in real contaminated sediments using a big cell, periodic voltage and innovative surfactants. J. Hazard. Mater. 320, 376-385. https://doi.org/10.1016/j.jhazmat.2016.08.003

Hahladakis, J.N., Lekkas, N., Smponias, A., Gidarakos, E., 2014. Sequential application of chelating agents and innovative surfactants for the enhanced electroremediation of real sediments from toxic metals and PAHs. Chemosphere 105, 44-52. https://doi.org/10.1016/j.chemosphere.2013.11.022

Harbottle, M.J., Lear, G., Sills, G.C., Thompson, I.P., 2009. Enhanced biodegradation of pentachlorophenol in unsaturated soil using reversed field electrokinetics. J. Environ. Manage. 90, 1893-1900. https://doi.org/10.1016/j.jenvman.2008.12.012

Hassan, I, Mohamedelhassan, E., Yanful, E.K., 2015. Solar powered electrokinetic remediation of $\mathrm{Cu}$ polluted soil using a novel anode configuration. Electrochim. Acta 181, 58-67. https://doi.org/10.1016/j.electacta.2015.02.216 
Hassan, I., Mohamedelhassan, E., Yanful, E.K., Yuan, Z.C., 2016a. A review article : electrokinetic bioremediation current knowledge and new prospects. Adv. Microbiol. 6, 57-72. https://doi.org/10.4236/aim.2016.61006

Hassan, I., Mohamedelhassan, E., Yanful, E., Bo, M.W., 2016b. Enhanced electrokinetic bioremediation by $\mathrm{pH}$ stabilisation. Environ. Geotech. https://doi.org/10.1680/jenge.16.00001

Huang, D., Xu, Q., Cheng, J., 2012. Electrokinetic remediation and its combined technologies for removal of organic pollutants from contaminated soils. Int. J. Electrochem. Sci. 7, 45284544.

Katz, S.A., Chilingar, G. V., Loo, W.W., Khilyuk, L.F., 1997. Electrobioremediation of soils contaminated with hydrocarbons and metals: progress report. Energy Sources 19, 129-146. https://doi.org/10.1080/00908319708908838

Kaya, A., Yukselen, Y., 2005. Zeta potential of soils with surfactants and its relevance to electrokinetic remediation. J. Hazard. Mater. 120, 119-126. https://doi.org/10.1016/j.jhazmat.2004.12.023

Khodadadi, a, Yousefi, D., Ganjidoust, H., Yari, M., 2011. Bioremediation of diesel-contaminated soil using Bacillus sp. ( strain TMY-2 ) in soil by uniform and non- uniform electrokinetic technology field. J. Toxicol. Environ. Heal. Sci. 3 (15), 376-384.

Kim, B.-K., Baek, K., Ko, S.-H., Yang, J.-W., 2011. Research and field experiences on electrokinetic remediation in South Korea. Sep. Purif. Technol. 79, 116-123. https://doi.org/10.1016/j.seppur.2011.03.002

Kim, S.-H., Han, H.-Y., Lee, Y.-J., Kim, C.W., Yang, J.-W., 2010. Effect of electrokinetic remediation on indigenous microbial activity and community within diesel contaminated soil. Sci. Total Environ. 408, 3162-3168. https://doi.org/10.1016/j.scitotenv.2010.03.038

Kim, S.-J., Park, J.-Y., Lee, Y.-J., Lee, J.-Y., Yang, J.-W., 2005. Application of a new electrolyte circulation method for the ex situ electrokinetic bioremediation of a laboratory-prepared pentadecane contaminated kaolinite. J. Hazard. Mater. 118, 171-176. https://doi.org/10.1016/j.jhazmat.2004.10.016

Kim, W.-S., Jeon, E.-K., Jung J.-M., Jung H.-B., Ko, S.-H., Seo, C.-I., Baek, K. 2013. Field application of electrokinetic remediation for multi-metal contaminated paddy soil using two-dimensional electrode configuration. Environ. Sci. Pollut. Res. 21 (6), 4482-4491. https://doi.org/10.1007/s11356-013-2424-0

Lahel, A., Fanta, A.B., Sergienko, N., Shakya, M., Lopez, M.E., Behera, S.K., Rene, E.R., Park, H.S., 2016. Effect of process parameters on the bioremediation of diesel contaminated soil by 
mixed microbial consortia. Int. Biodeterior. Biodegrad. 113, 375-385. https://doi.org/10.1016/j.ibiod.2016.05.005

Lear, G., Harbottle, M.J., Sills, G., Knowles, C.J., Semple, K.T., Thompson, I.P., 2007. Impact of electrokinetic remediation on microbial communities within PCP contaminated soil. Environ. Pollut. 146, 139-146. https://doi.org/10.1016/j.envpol.2006.06.037

Lear, G., Harbottle, M.J., Van der Gast, C.J., Jackman, S.A., Knowles, C.J., Sills, G., Thompson, I.P., 2004. The effect of electrokinetics on soil microbial communities. Soil Biol. Biochem. 36, 1751-1760. https://doi.org/10.1016/j.soilbio.2004.04.032

Lee, Y.-J., Choi, J.-H., Lee, H.-G., Ha, T.-H., Bae, J.-H., 2012. Effect of electrode materials on electrokinetic reduction of soil salinity. Sep. Sci. Technol. 47, 22-29. https://doi.org/10.1080/01496395.2011.607205

Lee, Y.-C., Woo, S.G., Choi, E.-S., Ahn, Y., Park, J., Lee, M., Yang, J.W., 2012. Bench-scale ex situ diesel removal process using a biobarrier and surfactant flushing. J. Ind. Eng. Chem. 18, 882-887. https://doi.org/10.1016/j.jiec.2012.01.020

Li, D., Niu, Y.Y., Fan, M., Xu, D.L., Xu, P., 2013. Focusing phenomenon caused by soil conductance heterogeneity in the electrokinetic remediation of chromium (VI)$\begin{array}{llllll}\text { contaminated } & \text { soil. } & \text { Sep. } & \text { Purif. } & \text { Technol. }\end{array}$ https://doi.org/10.1016/j.seppur.2013.09.018

Li, D., Tan, X.Y., Wu, X.D., Pan, C., Xu, P., 2014. Effects of electrolyte characteristics on soil conductivity and current in electrokinetic remediation of lead-contaminated soil. Sep. Purif. Technol. 135, 14-21. https://doi.org/10.1016/j.seppur.2014.07.048

Li, D., Xiong, Z., Nie, Y., Niu, Y.Y., Wang, L., Liu, Y.Y., 2012a. Near-anode focusing phenomenon caused by the high anolyte concentration in the electrokinetic remediation of chromium (VI)-contaminated soil. J. Hazard. Mater. 229-230, 282-291. https://doi.org/10.1016/j.jhazmat.2012.05.107

Li, F., Guo, S., Hartog, N., 2012b. Electrokinetics-enhanced biodegradation of heavy polycyclic aromatic hydrocarbons in soil around iron and steel industries. Electrochim. Acta 85, 228234. https://doi.org/10.1016/j.electacta.2012.08.055

Li, T., Guo, S., Wu, B., Li, F., Niu, Z., 2010. Effect of electric intensity on the microbial degradation of petroleum pollutants in soil. J. Environ. Sci. 22, 1381-1386. https://doi.org/10.1016/S1001-0742(09)60265-5

Li, T., Guo, S., Wu, B., Zhang, L., Gao, Y., 2015. Effect of polarity-reversal and electrical intensity on the oil removal from soil. J. Chem. Technol. Biotechnol. 90, 441-448. https://doi.org/10.1002/jctb.4312 
Li, T., Wang, Y., Guo, S., Li, X., Xu, Y., Wang, Y., Li, X., 2016. Effect of polarity-reversal on electrokinetic enhanced bioremediation of pyrene contaminated soil. Electrochim. Acta 187, 567-575. https://doi.org/10.1016/j.electacta.2015.11.097

Lim, M.W., Lau, E.V., Poh, P.E., 2016. A comprehensive guide of remediation technologies for oil contaminated soil - present works and future directions. Mar. Pollut. Bull. 109, 14-45. https://doi.org/10.1016/j.marpolbul.2016.04.023

Lima, A.T., Hofmann, A., Reynolds, D., Ptacek, C.J., Cappellen, P.V., Ottosen, L.M., Pamukcu, S., Alshawabekh, A., O’Carrol, D.M., Riis, C., Cox, E., Gent, D.B., Landis, R., Wang, J., Chowdhury, A.I.A., Secord, E.L., Hachair, A.S., 2017. Environmental electrokinetics for a $\begin{array}{llll}\text { sustainable } \quad \text { subsurface. } & \text { Chemosphere }\end{array}$ https://doi.org/10.1016/j.chemosphere.2017.03.143

Lima, A.T., Kleingeld, P.J., Heister, K., Loch, J.P.G., 2011. Removal of PAHs from contaminated clayey soil by means of electro-osmosis. Sep. Purif. Technol. 79, 221-229. https://doi.org/10.1016/j.seppur.2011.02.021

Lin, W., Guo, C., Zhang, H., Liang, X., Wei, Y., Lu, G., Dang, Z., 2016. Electrokinetic-enhanced remediation of phenanthrene-contaminated soil combined with Sphingomonas sp. GY2B and biosurfactant. Appl. Biochem. Biotechnol. 178, 1325-1338. https://doi.org/10.1007/s12010-015-1949-8

Luo, Q., Wang, H., Zhang, X., Fan, X., Qian, Y., 2006. In situ bioelectrokinetic remediation of phenol-contaminated soil by use of an electrode matrix and a rotational operation mode. Chemosphere 64, 415-422. https://doi.org/10.1016/j.chemosphere.2005.11.064

Maillacheruvu, K.Y., Chinchoud, P.R., 2011. Electrokinetic transport of aerobic microorganisms under low-strength electric fields. J. Environ. Sci. Health. A. Tox. Hazard. Subst. Environ. Eng. 46, 589-595. https://doi.org/10.1080/10934529.2011.562832

Mao, X., Wang, J., Ciblak, A., Cox, E.E., Riis, C., Terkelsen, M., Gent, D.B., Alshawabkeh, A.N., 2012. Electrokinetic-enhanced bioaugmentation for remediation of chlorinated solvents contaminated clay. J. Hazard. Mater. 213-214, 311-317. https://doi.org/10.1016/j.jhazmat.2012.02.001

Marks, R.E., Acar, Y.B., Gale, R.J., inventors; Electrokinetics, Inc., Baton Rouge, La., assignee. 1995. Insitu bio-electrokinetic remediation of contaminated soils containing hazardous mixed waste. US patent, 5,458,747. Oct. 17, 1995.

Maturi, K., Reddy, K.R., Cameselle, C., 2009. Surfactant-enhanced electrokinetic remediation of mixed contamination in low permeability soil. Sep. Sci. Technol. 44, 2385-2409. https://doi.org/10.1080/01496390902983745 
Mena, E., Rubio, P., Cañizares, P., Villaseñor, J., Rodrigo, M.A., 2012. Electrokinetic transport of diesel-degrading microorganisms through soils of different textures using electric fields. J. Environ. Sci. Health. A. Tox. Hazard. Subst. Environ. Eng. 47, 274-279. https://doi.org/10.1080/10934529.2012.640906

Mena, E., Villaseñor, J., Cañizares, P., Rodrigo, M.A., 2014. Effect of a direct electric current on the activity of a hydrocarbon-degrading microorganism culture used as the flushing liquid in soil remediation processes. Sep. Purif. Technol. 124, 217-223. https://doi.org/10.1016/j.seppur.2014.01.027

Mena, E., Ruiz, C., Villaseñor, J., Rodrigo, M.A., Cañizares, P., 2015. Biological permeable reactive barriers coupled with electrokinetic soil flushing for the treatment of dieselpolluted clay soil. J. Hazard. Mater. 283, 131-139. https://doi.org/10.1016/j.jhazmat.2014.08.069

Mena, E., Villaseñor, J., Cañizares, P., Rodrigo, M.A., 2016a. Influence of electric field on the remediation of polluted soil using a biobarrier assisted electro-bioremediation process. Electrochim. Acta 190, 294-304. https://doi.org/10.1016/j.electacta.2015.12.133

Mena, E., Barba, S., Saez, C., Navarro, V., Villaseñor, J., Rodrigo, M.A., Cañizares, P., $2016 b$. Prescale-up of electro-bioremediation process. In: Zekkos D, Farid ADA, Reddy KR (eds) Geo-Chicago 2016: sustainable waste management and remediation. American Society of Civil engineers, Reston, VA, pp 264-273. https://doi.org/10.1061/9780784480168.027

Mena, E., Villasenor, J., Rodrigo, M.A., Canizares, P., 2016c. Electrokinetic remediation of soil polluted with insoluble organics using biological permeable reactive barriers: effect of periodic polarity reversal and voltage gradient. Chem. Eng. J. 299, 30-36. https://doi.org/10.1016/j.cej.2016.04.049

Moghadam, M.J., Moayedi, H., Sadeghi, M.M., Hajiannia, A., 2016. A review of combinations of electrokinetic applications. Environ. Geochem. Health 38, 1217-1227. https://doi.org/10.1007/s10653-016-9795-3

Mokhtarani, B., Babaei, S., Mortaheb, H.R., Heidar, K.T., 2016. Effect of electrokinetic on biodegradation of fluorene and phenanthrene in soil. Iran. J. Chem. Eng. 13, 71-79.

Niqui-Arroyo, J.-L., Bueno-Montes, M., Posada-Baquero, R., Ortega-Calvo, J.-J., 2006. Electrokinetic enhancement of phenanthrene biodegradation in creosote-polluted clay soil. Environ. Pollut. 142, 326-332. https://doi.org/10.1016/j.envpol.2005.10.007

Olszanowski, A., Piechowiak, K., 2006. The use of an electric field to enhance bacterial movement and hydrocarbon biodegradation in soils. Pol. J. Environ. Stud. 15, 303-309. 
Paramkusam, B.R., Srivastava, R.K., Mohan, D., 2015. Electrokinetic removal of mixed heavy metals from a contaminated low permeable soil by surfactant and chelants. Environ. Earth Sci. 73, 1191-1204. https://doi.org/10.1007/s12665-014-3474-4

Park, J.Y., Lee, H.H., Kim, S.J., Lee, Y.J., Yang, J.W., 2007. Surfactant-enhanced electrokinetic removal of phenanthrene from kaolinite. J. Hazard. Mater. 140, 230-236. https://doi.org/10.1016/j.jhazmat.2006.06.140

Pazos, M., Alcantara, M.T., Rosales, E., Sanroman, M.A., 2011. Hybrid technologies for the remediation of diesel fuel polluted soil. Chem. Eng. Technol. 34, 2077-2082. https://doi.org/10.1002/ceat.201100192

Perez-Corona, M., Ochoa, B., Cardenas, J., Hernandez, G., Solis, S., Fernandez, R., Teutli, M., Bustos, E., 2013. Comparison of different arrangements of electrodes during the electrokinetic treatment of polluted soil with hydrocarbons and its final application in situ. Recent Res. Devel. Electrochem. 9, 59-80. ISBN: 978-81-7895-594-0

Pham, T.D., Sillanpää, M., 2015. Electrokinetic remediation of organic contamination. Environ. Technol. Rev. 4, 103-117. https://doi.org/10.1080/21622515.2015.1105306

Ramírez, E.M., Camacho, J.V., Rodrigo, M.A., Canizares, P., 2015. Combination of bioremediation and electrokinetics for the in-situ treatment of diesel polluted soil: a comparison of $\begin{array}{lllll}\text { strategies. } & \text { Sci. } & \text { Total } & \text { 307-316. }\end{array}$ https://doi.org/10.1016/j.scitotenv.2015.06.127

Ramírez, E.M., Camacho, J.V., Rodrigo, M.A., Cañizares, P., 2014. Feasibility of electrokinetic oxygen supply for soil bioremediation purposes. Chemosphere 117, 382-387. https://doi.org/10.1016/j.chemosphere.2014.07.075

Ramírez, E.M., Jiménez, C.S., Camacho, J.V., Rodrigo, M.A., Cañizares, P., 2015. Feasibility of coupling permeable bio-barriers and electrokinetics for the treatment of diesel hydrocarbons polluted soils. Electrochim. Acta 181, 192-199. https://doi.org/10.1016/j.electacta.2015.02.201

Reddy, K.R., Cameselle, C., 2010. Integrated electrokinetic-soil flushing to remove mixed organic and metal contaminants. J. Appl. Electrochem. 40, 1269-1279. https://doi.org/10.1007/s10800-010-0102-1

Reddy, K.R., Chinthamreddy, S., 2004. Enhanced electrokinetic remediation of heavy metals in glacial till soils using different electrolyte solutions. J. Environ. Eng. 130, 442-455. https://doi.org/10.1061/(ASCE)0733-9372(2004)130:4(442)

Ren, X., Zeng, G., Tang, L., Wang, J., Wan, J., Liu, Y., Yu, J., Yi, H., Ye, S., Deng, R., 2018. Sorption, transport and biodegradation - an insight into bioavailability of persistent 
organic pollutants in soil. Sci. Total Environ. 610-611, 1154-1163. https://doi.org/10.1016/j.scitotenv.2017.08.089

Risco, C., Rodrigo, S., Vizcaíno, R.L., Yustres, A., Saez, C., Cañizares, P., Navarro, V., Rodrigo, M.A., 2016. Removal of oxyfluorfen from spiked soils using electrokinetic soil flushing with linear rows of electrodes. Chem. Eng. J. 294, 65-72. https://doi.org/10.1016/j.cej.2016.02.112

Saichek, R.E., Reddy, K.R., 2005. Surfactant-enhanced electrokinetic remediation of polycyclic aromatic hydrocarbons in heterogeneous subsurface environments. J. Environ. Eng. Sci. 4, 327-339. https://doi.org/10.1139/S04-064

She, P., Song, B., Xing, X.-H., Loosdrecht, M.V., Liu, Z., 2006. Electrolytic stimulation of bacteria Enterobacter dissolvens by a direct current. Biochem. Eng. J. 28, 23-29. https://doi.org/10.1016/j.bej.2005.08.033

Shi, L., Müller, S., Harms, H., Wick, L.Y., 2008. Factors influencing the electrokinetic dispersion of PAH-degrading bacteria in a laboratory model aquifer. Appl. Microbiol. Biotechnol. 80, 507-515. https://doi.org/10.1007/s00253-008-1577-0

Souza, F.L., Llanos, J., Saez, C., Lanza, M.R.V., Rodrigo, M.A., Canizares, P., 2016. Performance of wind-powered soil electroremediation process for the removal of 2,4-D from soil. J. Environ. Manage. 171, 128-32. https://doi.org/10.1016/j.jenvman.2016.01.032

Tiehm, A., Lohner, S.T., Augenstein, T., 2009. Effects of direct electric current and electrode reactions on vinyl chloride degrading microorganisms. Electrochim. Acta 54, 3453-3459. https://doi.org/10.1016/j.electacta.2009.01.002

Environmental Protection Agency, 2017. Superfund remedy report, 15th edition. Final Report. Office of Land and Emergency Management, U.S. Environmental Protection Agency. Report No. EPA-542-R-17-001.

Environmental Protection Agency, 2007. Electrochemical remediation technologies (ECRTs) - In situ remediation of contaminated marine sediments. National Risk Management Research Laboratory, Office of Research and Development, U.S. Environmental Protection Agency. Report No. EPA/540/R-04/507.

Vieira dos Santos, E., Medeiros, M.O., Dantas dos Anjos, A.S., Martínez-huitle, C.A., Ribeiro da Silva, D., 2014. Application of electrochemical technologies to treat polluted soil by diesel. Chem. Eng. Trans. 41, 157-162. https://doi.org/10.3303/CET1441027

Vieira dos Santos, E., Souza, F., Saez, C., Cañizares, P., Lanza, M.R.V., Martinez-Huitle, C.A., Rodrigo, M.A., 2016. Application of electrokinetic soil flushing to four herbicides : a $\begin{array}{lll}\text { comparison. } & \text { Chemosphere } 205-211 .\end{array}$ https://doi.org/10.1016/j.chemosphere.2016.03.047 
Wang, C., Zhang, Z., Xu, W., Sun, H., 2016. Electrokinetic-assisted bioremediation of field soil with historic polycyclic aromatic hydrocarbon contamination. Environ. Eng. Sci. 33. https://doi.org/10.1089/ees.2014.0286

Wang, J.-Y, Huang, X.-J, Kao, J.C.M., Stabnikova, O., 2007. Simultaneous removal of organic contaminants and heavy metals from kaolin using an upward electrokinetic soil remediation process. J. Hazard. Mater. 144, 292-299. https://doi.org/10.1016/j.jhazmat.2006.10.026

Wick, L.Y., Mattle, P.A., Wattiau, P., Harms, H., 2004. Electrokinetic transport of PAH-degrading bacteria in model aquifers and soil. Environ. Sci. Technol. 38, 4596-4602. https://doi.org/10.1021/es0354420

Wick, L.Y., Shi, L., Harms, H., 2007. Electro-bioremediation of hydrophobic organic soilcontaminants: a review of fundamental interactions. Electrochim. Acta 52, 3441-3448. https://doi.org/10.1016/j.electacta.2006.03.117

Wu, X., Gent, D.B., Davis, J.L., Alshawabkeh, A.N., 2012. Lactate injection by electric currents for bioremediation of tetrachloroethylene in clay. Electrochim. Acta 86, 157-163. https://doi.org/10.1016/j.electacta.2012.06.046

Xu, W., Wang, C., Liu, H., Zhang, Z., Sun, H., 2010. A laboratory feasibility study on a new electrokinetic nutrient injection pattern and bioremediation of phenanthrene in a clayey soil. J. Hazard. Mater. 184, 798-804. https://doi.org/10.1016/j.jhazmat.2010.08.111

Yan, F., Reible, D., 2015. Electro-bioremediation of contaminated sediment by electrode enhanced $\begin{array}{llll}\text { capping. } & \text { J. } & \text { Environ. } & \text { 154-161. }\end{array}$ https://doi.org/10.1016/j.jenvman.2015.03.023

Yang, J.-W, Lee, Y.-J, Park, J.-Y, Kim, S.-J, Lee, J.-Y, 2005. Application of APG and Calfax 16L35 on surfactant-enhanced electrokinetic removal of phenanthrene from kaolinite. Eng. Geol. 77, 243-251. https://doi.org/10.1016/j.enggeo.2004.07.015

Yeung, A.T., Gu, Y.-Y., 2011. A review on techniques to enhance electrochemical remediation of contaminated soils. J. Hazard. Mater. 195, 11-29. https://doi.org/10.1016/j.jhazmat.2011.08.047

Yuan, Y., Guo, S.-H., Li, F.-M., Li, T.-T., 2013. Effect of an electric field on n-hexadecane microbial degradation in contaminated soil. Int. Biodeterior. Biodegrad. 77, 78-84. https://doi.org/10.1016/j.ibiod.2012.10.012

Zhao, S., Fan, L., Zhou, M., Zhu, X., Li, X., 2016. Remediation of copper contaminated kaolin by electrokinetics coupled with permeable reactive barrier. Procedia Environ. Sci. 31, 274279. https://doi.org/10.1016/j.proenv.2016.02.036 
Zhong, H., Liu, G., Jiang, Y., Yang, J., Liu, Y., Yang, X., Liu, Z., Zeng, G., 2017. Transport of bacteria in porous media and its enhancement by surfactants for bioaugmentation: a review. Biotechnol. Adv. https://doi.org/10.1016/j.biotechadv.2017.03.009 